\title{
Nazilli Yahya Paşa (Eski-Yeni) Cami Haziresi Mezar Taşları
}

\author{
Evren GÖKÇE ${ }^{1}$
}

\begin{abstract}
$\ddot{O} \mathbf{z}$
Osmanlı sosyo-kültürel hayatı hakkında önemli bilgiler içeren kaynaklardan birisi mezar taşlarıdır. Osmanlı mezar taşları sayesinde arşiv belgelerine yansımayan önemli detaylar tespit edilebilmektedir. $\mathrm{Bu}$ durum mezar taşlarının tarih araştırmalarındaki önemini artırmaktadır. Başkent İstanbul'un yanı sıra Anadolu'da bulunan birçok şehirde bulunan mezar taşları çeşitli inceleme ve araştırmalara konu teşkil etmektedir.
\end{abstract}

XIX. yüzyılın ikinci yarısından sonra büyüyerek Aydın'da önemli bir yerleşim merkezi olan Nazilli'de Osmanlı döneminden kalma tarihi eserlerin sayısı azdır. $\mathrm{Bu}$ tarihi eserler ağırlıklı olarak cami, mescit ve türbe gibi dini yapılardır. $\mathrm{Bu}$ yapılardan bazılarının bünyesinde küçük çaplı hazireler mevcuttur. Bu hazirelerde şehir tarihi açısından önem arz eden Osmanlı dönemine ait mezar taşları bulunmaktadır.

Aşağı Nazilli bölgesinde bulunan Yahya Paşa Cami bünyesinde Osmanlı mezar taşlarının bulunduğu bir hazire barındırmaktadır. Caminin güney batı köşesinde yer alan hazirede on dört adet mezar taşı bulunmaktadır. Bu çalışmada söz konusu hazirede bulunan mezar taşları incelenmiştir. Böylece Osmanlı mezar taşı ve Nazilli tarihi araştırmalarına katkı sağlanması hedeflenmiştir.

Anahtar Kelimeler: Osmanı Mezar Taşları, Yahya Paşa Cami, Hazire, Nazilli

\section{Nazilli Yahya Paşa (Eski-Yeni) Mosque Graveyard Tombstones}

\begin{abstract}
:
The Ottoman tombstones are sources that include important pieces of information and data about socio-cultural life. Thanks to tombstones, some important details which are not found among the Ottoman archive documents. Thus, the importance of tombstones in historical researches is increasing. Besides İstanbul, tombstones which exist in numerous Anatolian settlements, were subjected to various examinations and researches.

The Ottoman historical artifacts are rare in Nazilli, a town which developed in the second half of 19th century and became one of the most important settlements in Aydin. These places are generally religious types as mosque, masjid, and mousoleum. In historical places of the town, there are some small-scale enclosed graveyards. At these enclosed graveyards, there are Ottoman tombstones which are important for the local history.

Yahya Paşa Mosque, which was constructed in the Lower Nazilli, has an historical graveyard that where Ottoman tombstones exist. There are fourteen tombstones in the graveyard which was located at the southwestern corner of the Mosque. In this article, Ottoman tombstones at Yahya Paşa Mosgue's graveyard were examined
\end{abstract}

\footnotetext{
${ }^{1}$ Tarih doktoru. E-posta: evren1839@hotmail.com. Orcid: 0000-0001-5930-3020
} 
and analyzed, and it is also planned that contribute Ottoman tombstone researches to the local history of Nazilli

Keywords: Ottoman tombstones, Yahya Paşa Mosque, Graveyard, Nazilli

\section{Giriş}

Osmanlı medeniyeti söz konusu olunca akla ilk gelen unsurlardan birisi olan mezar taşları, aynı zamanda arşiv belgelerine yansımayan bilgilerin elde edildiği önemli kaynaklardır. Geçmişte çeşitli nedenlerle meydana gelen yoğun tahribat ve yok olmalara rağmen, günümüze çok sayıda Osmanlı mezar taşı ulaşmıştır. Bu taşların önemi her geçen gün daha iyi anlaşılarak korunmaları için gereken tedbirler alınmakta, mümkün olduğunca yok olmalarının önüne geçilmektedir. Osmanlı mezar taşları, bu nitelikleriyle tarihin somut kanıtları olma niteliğine sahiptirler.

Osmanlı İmparatorluğu döneminde Aydın sancağının kazalarından olan Nazilli, XIX. yüzyılın ikinci yarısından itibaren ciddi bir gelişim süreci yaşamıştır. I. Dünya Savaşı ve sonrasında yaşanan işgal ile birlikte bu süreç sekteye uğramakla birlikte, Cumhuriyet'in ilanından sonra Nazilli yeniden aynı sürecin içine girmiş ve günümüzde Türkiye'nin en büyük ilçelerinden birisi haline gelmiştir. Osmanlı döneminde nüfusun ağırlıklı olarak Aşağı Nazilli olarak bilinen bölgede yaşadığı şehirde, 1881 tarihinden itibaren demiryolunun geçmesiyle birlikte Yukarı Nazilli yani Pazarköy bölgesi büyümüş, zamanla şehrin iki ana yerleşiminden birisini oluşturmuştur.

Şehrin temel yerleşimini teşkil ettiği için tarihi eserlerin istisnalar hariç tamamına yakını Aşağı Nazilli'de bulunmaktadır. Bunlardan birisi, Yahya Paşa veya diğer adıyla Eski-Yeni Cami'dir. Yahya Paşa Cami aynı zamanda şehirde az sayıdaki hazirelerden birisini barındırmaktadır. Caminin güneybatı köşesinde bulunan hazirede on iki adet Osmanlı mezar taşı günümüze gelmiştir. Bu incelemede Yahya Paşa Cami haziresindeki söz konusu mezar taşları mercek altına alınmıştır. İlk aşamada bu taşlarda mevcut kitabelerin günümüz Türkçesine transkripsiyonu yapılmıştır. İkinci aşamada ise şekil, süsleme ve başlık gibi teknik özellikler incelenmiştir. $\mathrm{Bu}$ aşamalardan sonra elde edilen veriler çeşitli açılardan değerlendirilip birtakım sonuçlara ulaşılmaya çalışılmış ve Nazilli'nin sosyo-kültürel tarihi hakkında yapılan çalışmalara katkı sağlanması hedeflenmiştir.

\section{Nazilli Yahya Paşa (Eski Yeni) Camii}

Nazilli'deki Osmanlı dönemi camilerinden olan Yahya Paşa Cami, şehrin Aşağı Nazilli olarak bilinen bölgesinde bulunmaktadır. Caminin kuzey yönünde bulunan üst tarafinda 208 sokak üzerinde, Aşağı Nazilli'deki bulunan başka bir Osmanlı dönemi eseri olan Ağa Cami mevcuttur. Mevki olarak Dumlupınar mahallesinde 361 sokak ile 208 sokağın kesişim yaptığı noktada yer alan Yahya Paşa Cami'nin giriş kısmı, kuzeybatıya doğru bakmakta olup Yukarı Nazilli yönüne, kıble yönü ise güney batıya doğru Nazilli ovasına bakmaktadır. (Harita-I-II) Cami sâlnâmelere göre Osmanlı döneminde Hüseyin Hasan mahallesi sınırlarında kalmakta, avlusunda Yahya Paşa Medresesi adlı eğitim kurumu bulunmaktaydı. (Sâlnâme-i Nezâret-i Maârif-i Umûmiye, 1321: 376) 
Kaynaklarda hakkında pek bilgiye rastlanmayan Yahya Paşa Cami hakkında Vakıflar Genel Müdürlüğü tarafından yayınlanan Türkiye'de Vakıf Abideleri ve Eski Eserler isimli eserde caminin aynı zamanda Eski-Yeni Cami olarak bilindiği belirtilmekte, fakat yapım tarihi ve banisi hakkında herhangi bir bilgiye yer verilmemektedir. Bununla birlikte yapılan restorasyondan sonra kapısina banisinin Yahya Paşa olduğuna dair bir yazı konulmuş ve yapım tarihi olarak 1573 yılı belirtilmiştir. (Türkiye'de Vakıf Abideleri ve Eski Eserler, 1963: 709; Resim-I-III)

Tescilli bir vakıf eseri olan cami mimari açıdan tek kubbeli, kare planlı ve kubbe kasnağı iki kademelidir. Ana mekân beden duvarları üzerine dört köşede dört payanda ile desteklenmiştir. Cami pandatifleri ile iç süslemeleri basit şablon süslemeli olup, kubbesinde yer alan barok kabartma dışında diğer süslemeleri baskı süslemedir. Mihrap kemerinin üzerinde alçı süslemeler bulunmaktadır. (Türkiye'de Vakıf Abideleri ve Eski Eserler,709; Aydın İl Kültür Müdürlüğü Envanteri-I, 2012:344)

Özellikle iç süslemeler açısından zengin bir görünüm arz eden camide, iç mekânın kuzeyini kaplayan üst kattaki mahfil, günümüzde kadınlar için ayrılmıştır. Buraya çıkış son cemaat yerinin batısında yer alan minare merdivenlerinin altındaki girişten sağlanmaktadır. Mihrabı alçıdan olan caminin minberi ahşaptır. Beden duvarları iki kademe olarak yükselen camide simetrik olarak iki sıra pencereler mevcuttur. Minare, iç mekân ile son cemaat yerinin birleştiği yerin kuzeybatısında sekizgen gövdeli kaide üzerinde silindirik olarak yükselmektedir. İç süslemeler dışında mihrap ve kubbe merkezindeki süslemeler alçı kabartma tekniği ile yapılmıştır. Diğer süslemelerin ise yaş sıva üzerine boya (fresco buono) ve şablon teknikleri ile yapıldığı düşünülmektedir. Barok ve rokoko gibi batı tarzı sanatların kullanıldığ1 süsleme kompozisyonlarında kırmızı, siyah, mavi vb. renklere yer verilmiştir. Kompozisyonlarda aynı zamanda bitki, yaprak, madalyon gibi unsurlar mevcuttur. Bazı madalyonların içinde Allah, Hz. Muhammed, dört halife, Hz. Hasan, Hz. Hüseyin ve Bilal Habeşî isimleri yer almakta, mihrabın önündeki panoda ise Allah lafzıyla, Ali İmran Sûresi'nin 37. ayeti (Kullemâ dehale aleyke Zekeriyye'l-mihrâb) bulunmaktadır. (Yurtsal, 2009: 35-37)

Caminin imâm-hatibi sn. Mesut Atanak tarafından verilen bilgilere göre, Yahya Paşa Camii Kâbe ölçülerinde inşa edilmiştir. İç mekânda bulunan kürsü ve ahşap işlemeler orjinaldir. Kalınlığ $1.40 \mathrm{~cm}$. olan duvarların dış tarafında iç mekân ile bağlantılı delikler mevcut olup bu delikler vasıtası ile rutubet ve nem sorunu çözüme kavuşturulmuştur. Caminin bulunduğu Aşağı Nazilli bölgesinde bulunan evlerde rutubet ve nem sebebiyle sivalar dökülmekte iken camide bu tedbir sebebiyle benzer sorunlar yaşanmamaktadır. Ayrıca, caminin dört köşesinin önlerine yapılmış olan bir metre derinliğe sahip kapaklı kanallar vasıtasıyla rutubet önlendiği gibi, su baskınlarının önüne geçilmesi hedeflenmiştir. İç mekânda örümcek ağ1 vb. oluşmaması için caminin duvarlarında kullanılan harca deve kuşu yumurtası karıştırılmıştır. Dış avluda bugün bahçe olan yerin kuzey batısında eski dönemlerde eğitim verilen Yahya Paşa Medresesi'nin temel kalıntıları mevcuttur. Bahçe ile cami avlusunu birbirinden ayıran beton çitleri birleştiren süslemeli stilize mermer sütunlar eski dönemlerden kalmadır. Abdest alınan yerin yanında yerde devrik şekilde bir sütun mevcut olup, Roma- Bizans dönemine ait oldukları tahmin edilmektedir. 
Sn. Atanak tarafından verilen diğer bilgilere göre, caminin tezyinatında kullanılan bitkisel karakterli süslemeler arasında, üst katta kadınlar mahfilinin hemen girişinde bulunan pandatif motifi orjinalliğini korumaktadır. Son restorasyon sırasında, daha önce yapılan sıvanın altından çıkarılan motif olduğu gibi bırakılmıştır. Caminin duvarlarında madalyonlar içinde bulunan hat levhaları arasındaki celi-sülüs müsenna Hasan Hüseyin hattı ise dikkat çeken ve nadir görülen bir eserdir. Kadınlar mahfiline girilen ve müezzine ayrılmış yerin karşısında bulunan kısımdan aynı zamanda minareye çıkılmaktadır. Bu özellik, cami mimarisindeki dikkat çekici unsurlardandır. Cami kapısının muhtemelen XIX. yüzyıl veya öncesinden kalma olan anahtarı ise hala kullanılmaktadır. İç mekanla birleşik olan son cemaat yerinin üstünü kapatan kubbeler ise başl1klı sütunlara oturtulmuştur. Bu sütunlar esasen ahşap olup, caminin bulunduğu bölgenin nemli ve rutubetli olması nedeniyle dışarıdan sıvayla kaplanmıştır. $^{2}$

\section{Yahya Paşa Cami Haziresi}

Yahya Paşa Cami haziresi, konum olarak caminin sağ beden duvarının yanında ve bu duvarın kıble yönündeki beden duvarı ile kesiştiği noktada bulunmaktadır. Caminin 361. sokakta yer alan sağ taraf girişinden başlayan bahçenin üzerinde bulunan hazire, bahçenin caminin sağ beden duvarıyla bitiştiği kısmın ucunda, üçgen bir şekil alarak sonlanmakta bu noktadan küçük bir aralıkla kıble yönüne geçilmektedir. Camiyi ve avluyu çevreleyen dış duvar aynı zamanda hazirenin dış duvarını teşkil etmektedir. Cami sağ beden duvarı ile hazire iç duvarı arasında ayrıca rutubet, nem ve su baskınlarını önlemek için yapılmış kanalın bir kısmı uzanmakta, kanal caminin kıble yönündeki beden duvarıyla sola dönmektedir. Hazire iç duvarı üç basamaklı bir taş merdiven ile ortasından ikiye bölünmüştür. Bu bölümlerden üst tarafta bulunan kısım kare şeklinde iken, altında kalan kısım ise bahçe ile camiyi çevreleyen dış duvarın bitişmesi ile üçgen şekline girmektedir. (Harita-II; Resim No: III-IV)

Hazirenin iç duvarı caminin 208. Sokak ile 361. sokağın kesiştiği yerde bulunan yan girişinden bahçe ile birlikte başlamakta, güney-güneybatı yönünde uzanmaktadır. Hazirenin bulunduğu kısma gelindiğinde iç duvar yukarıda belirtildiği gibi hazireye geçişi sağlayan üç basamaklı bir merdivenle ikiye ayrılmaktadır. Ayrıca hazirenin bulunduğu yerde üstü mermer plakalarla kaplanmıştır. Üç basamaklı merdivenle birbirinden ayrılan hazirenin ilk kısmı kare şeklinde olup, ikinci kısma nazaran üst tarafta bulunmaktadır. İkinci kısım ise camiyi çevreleyen dış duvar ile caminin kıble beden duvarının kesiştiği yerde olup, üçgen bir uçla sonlanmaktadır.

İkinci kısımda camiyi ve hazireyi çevreleyen dış duvarda açılmış bir demir şebekeli pencere mevcuttur. Bu sayede dışarıdan hazirenin içi kısmen görülebilmektedir. Demir şebekeler birbirlerinden geçmeli olarak yapılmış olup kare görünümlü ve beyaz boyalıdır. Pencerenin üst alt ve yanlarında üzerinde süslemeler

\footnotetext{
2 Araştırmamız esnasında her türlü kolaylığı gösteren caminin imam-hatibi sn. Mesut Atanak'a teşekkürü bir borç bilirim.
} 
olan mermer söveler bulunmaktadır. Sövelerden üstte olan bulunduğu yerden çıkarılmış olup hazirenin içinde duvara dayalı olarak durmaktadır. Yerinde bulunan diğer sövelerin üzerinde çeşitli süslemeler mevcuttur. Bu süslemelerde geleneksel, geometrik, nesnel ve bitkisel tarza motiflere yer verilmiştir. Bunların yatay, yuvarlak kemerli, dikdörtgen ve üçgen şeklinde silmeler, rozet, çarkıfelek, düğme, vazo, nar, armut, karanfil, lale, stilize yapraklar, dallar, sahan, çanak ve balık gibi motifler olduğu görülmektedir. (Resim No:III-V)

Yahya Paşa Cami haziresinde, üç ayaktaşı dokuz şahide olmak üzere toplam on iki mezar taşı mevcuttur. Taşlar karş1lıklı olarak gelişigüzel bir biçimde dikilmiştir. Caminin yakınında oturan bazı mahalle sakinleri taşların esasen buraya ait olmadıklarını, hazireye sonradan getirilerek dikildiklerini ifade etmektedirler. $\mathrm{Bu}$ durumun yanı sıra, taşlardaki düzensiz dizilim restorasyonlar sırasında yapılan müdahalelerle alakalı olabilir. Hazirede bulunan mezar taşları okunabilir durumda ve genel olarak sağlamdır. Bununla birlikte birkaç taşta başlık, gövde ve gövdenin toprakla birleştiği kısımlarda kırılmalar görülmektedir. (Resim No:III)

\section{Yahya Paşa Cami Haziresi Mezar Taşları}

\section{a-Müftizâde Hâcı Nûrî Efendi}

Şahide No:1

Ayaktaşı No:1

Ayaktaşı Çizim No:1

Başlık No:1

Sahibi: Hâcı Nûrî Efendi

Tarihi: H.8 Cemâziyülevvel 1327/ M.28 Mayıs 1909

Mezar Formu: Muhtemelen toprak mezar

Şahide Formu: Dikdörtgen kesitli erkek başl1klı

Ayaktaşı Formu: Dikdörtgen kesitli sivri kemerli

Malzemesi: Mermer

İşleniş Tekniği: Oyma ve kabartma

Kitabe Yazı Türü: Talîk

Kitabe Metni:

Hüve'l-baki 8 Cemâziyülevvel 1327

Müftizâde Mustafâ

Efendi mahdumu

Ulemâ-yı benâmdan Hâcı

Nûrî Efendi ruhuna

Fâtiha 
Genel Tanım: Dikdörtgen kesitli erkek başlıklı şahide yukarıdan aşağıya doğru hafif daralan formdadır. Şahidenin sağ omuz kısmında küçük bir kırılma mevcuttur. Şahideyi dikdörtgen bir bordür çevrelemektedir. Bordürün serlevhâ ve tarihin ibarelerinin bulunduğu kartuştu başlık boynundan ayıran kısmının kilit noktasında, yukarı doğru bir kaş kemer çıkıntısı bulunmaktadır. Serlevhâ ve tarih kartuşu aynı zamanda diğer kartuşlardan kısmen geniş olup, düzensiz dikdörtgen görünümü sergilemektedir. Dikdörtgen bordür Fâtiha ibaresinin bulunduğu kartuşun alt silmesine gelindiğinde ince bir şekil almakta, üzerinde iç ve dişa doğru dönük kaş kemer çıkıntıları bulunmaktadır. Altı satırdan oluşan talîk hatlı kitabe kuşağı diagonal olarak sağdan sola doğru hafifçe yükselmekte olup aynı durum satırları birbirinden ayıran kartuşlar için de geçerlidir.

Başlık: Kalın ve düz bir boyunla gövdeden ayrılan başlık, oval ve sarıklı başlık türündedir. Üst kısmı hafifçe görülen başlığı çevreleyen sarık, yatay ve kalın dilimlerle başlığı dolanmakta, ortaya gelindiğinde dilimler kalın bir dilimle birleşmektedir. Başlığın ön yüzünün tam ortasında bulunan ve diagonal olarak soldan sağa doğru yukarıya yükselen kalın dilim ise sarık dilimlerini ortadan ikiye ayırmaktadır. Bu kalın dilim aynı zamanda başlığa estetik bir görünüm sağlamaktadır. Başlığın arka yüzünde zamanın tahribatıyla görülen aşınma yüzünden sarık dilimleri görünmemektedir. $\mathrm{Bu}$ aşınma ile birlikte yüzeyde küçük çapta çatlamalar mevcuttur.

Ayaktaşı: Dikdörtgen kesitli sivri kemerli ayaktaşının sağ tarafı kırıktır. Ayaktaşı gövdesinde bitkisel bir süsleme kompozisyonu olarak servi ağacı motifine yer verilmiştir. Ancak bu motif görülemeyecek derecede silikleşmiştir.

\section{b-Hâcı Nûrî Mahdumu Mehmed Sâlih Efendi}

Şahide No:2

Başlık No: 2-3

Şahide Çizim No:1

Başlık Çizim No:1

Sahibi: Mehmed Sâlih Efendi

Tarihi: H.24 Zilka'de 1326/M.18 Aralık 1908

Mezar Formu: Muhtemelen toprak mezar

Şahide Formu: Dikdörtgen kesitli erkek başlıklı

Malzemesi: Mermer

İşleniş Tekniği: Oyma ve kabartma

Kitabe Yazı Türü: Talîk

Kitabe Metni:

Hüve'l-baki 24 Zilka'de 1326 


\author{
Dehre gelen akıbet eyler vefât \\ İşte bu da Mehmed Sâlih idi \\ Vasıl-ı seb'în hoş hâl idi. \\ Ömri ibâdet ile tâat idi. \\ Var ise günâhı ola afve karîn \\ Eyleye hâk cümle azâbdan emîn \\ Müderris Hâcı Nûrî Efendi \\ Mahdumu Mehmed Sâlih Efendi ruhuna Fâtiha
}

Genel Tanım: Dikdörtgen kesitli erkek başlıklı şahide hafifçe aşağıya doğru daralan formdadır. Şahide üzerinde diagonal olarak sağdan sola yükselen dokuz satırlık talîk hatlı kitabe kuşağı yer almaktadır. Kitabe satırları yine diagonal şekilde sağdan sola doğru yükselen düz silmelerle birbirinden ayrılmaktadır. Kitabe kuşağını çevreleyen dikdörtgen bordür, en üstte serlevhâ ve tarihin bulunduğu kartuşla başlik kısmını şahide gövdesinden ayırmakta, en altta dua veya Fâtiha ibaresinin bulunduğu kartuşun alt silmesinde yuvarlak şekle girmektedir. Serlevhâ ve tarihin bulunduğu kartuş diğer kartuşlara nazaran daha geniş olup düzensiz dikdörtgen görünümü arz etmektedir.

Başlık: Şahide başlığı düz bir boyun üzerinde yükselen sarıklı fes başlıktır. Başlığın bir kısmı görünmektedir. Başlık üzerindeki sarık ise soldan sağa diagonal veya çaprazlama olarak sarılmış olup ince dilimlerden oluşmaktadır. Hâcı Nûrî Efendi başlığında görüldüğü gibi, ortada bulunan ve diagonal olarak yine sağdan sola doğru yükselen kalım bir dilim bu dilimleri ikiye ayırmaktadır. Bu dilimlerden üsttekiler sol üst, alttakiler ise sol alt yönde ortadaki kalın dilimin altında toplanmaktadır. Bu şekilde başlığa yine estetik bir görünüm kazandırılmıştır. Başlığın arka yüzeyinde de benzer bir şekillendirme olmakla birlikte kalın bir dilime yer verilmemiştir. Fes başlığın tabla kısmı düz şekillendirilmiş olup tabla üzerinde püskül mevcut değildir.

\title{
c-Hâcı Kara Mehmedzâde İbrâhim Efendi
}

Şahide No:3

Başlık No:4-5-6

Şahide Çizim No:2

Başlık Çizim No:2-3

Sahibi: İbrâhim Efendi

Tarihi: R.30 Haziran 1323/M.13 Temmuz 1907

Mezar Formu: Muhtemelen toprak mezar 
Şahide Formu: Dikdörtgen kesitli erkek başlıklı

Malzemesi: Mermer

İşleniş Tekniği: Oyma ve kabartma

Kitabe Yazı Türü: Talîk

Kitabe Metni:

Hüve'l-bâkî 30 Hazîran 1323

İtdi rıhlet bu fenâdan İbrâhim Efendi

Nâmı hattât-ı şehr idi bu devr içre muhterem

Nûş idüb câm-ı ecelden basdı uhrâya kadem

Cennet-i âlâda virsün ana hakk dürlü niam

Hattât-ı şehr Hâcı Kara Mehmedzâde

Ibrâhim Efendi rûhuna Fâtiha

Genel Tanım: Dikdörtgen kesitli erkek başlıklı şahide yukarıdan aşağıya doğru hafifçe daralan formdadır. Talîk hatla yazılmış yedi satırlık kitabeyi dikdörtgen bir bordür çevrelemektedir. Bordür, serlevhâ ve tarihin bulunduğu kartuşun kilit taş1 noktasında yukarıya doğru dönük kaş kemer çıkıntısı yapmaktadır. Kitabe satırları soldan sağa hafif diagonal şekilde yükselmekte olup, aynı durum satırları birbirinden ayıran düz silmeler için de geçerlidir. Serlevhâ ve tarih ibarelerinin bulunduğu kartuş, diğer kartuşlara göre kısmen geniş olup düzensiz dikdörtgen görünümündedir. Kitabe kuşağını ve şahideyi çevreleyen dikdörtgen bordür Fatiha ibaresinin bulunduğu kartuşun alt silmesinde oval bir şekil almakta, ayrıca ortasında aşağıya doğru bir kaş kemer çıkıntısı bulunmaktadır.

Başlık: Şahide başlığı düz bir boyun üzerinden yükselen sarıklı fes başlıktan oluşmaktadır. Fes başlığı çevreleyen sarığın yatay sarılmış ilk dilimi çok az görülmekte olup alttaki dilimin içinde sokulmuştur. Alttaki yatay dilim ise başlı̆g 1 geniş bir biçimde çevrelemektedir. Her iki dilim hafif diagonal olarak sarılmıştır. Bununla birlikte fes başlığın üstünde geniş, sağ alt kısmında küçük boşluklar bırakılmıştır. Sarık dilimlerinin üzerinde bitkisel süsleme unsurları mevcuttur. Bu süslemelerin ince silmeler arasında soldan sağa doğru diagonal şekilde yükselen dörder yapraklı çiçek ve üçgen yaprak motifleri olduğu görülmektedir. Sarığın sarıldığı fes başlığın püskülü tabla kısmından başlayıp arkaya doğru indirilmiş ve sarığın içine sokulmuştur.

\section{ç-Ali Ağazâde Kızı Fâtma Kadın}

Şahide No:4

Şahide Çizim No:3

Sahibi: Fâtma Kadın

Tarihi: H.1159/M.1746-1747 
Mezar Formu: Muhtemelen toprak mezar

Şahide Formu: Dikdörtgen kesitli kadın başlıklı

Malzemesi: Mermer

İşleniş Tekniği: Oyma ve kabartma

Kitabe Yazı Türü: Sülüs

Kitabe Metni: $\quad$ Merhûme lehâ ve mağfûre lehâ

Ali Ă̆azâde kızı

Fâtma Kadın rûhı-çün

\section{El-Fâtiha}

\section{9}

Genel Tanım: Dikdörtgen kesitli sivri kemerli kadın başlıklı şahide omuzlardan itibaren yukarıdan aşağıya doğru hafifçe daralmaktadır. Omuz üstünde ise pahlar sebebiyle aşağıdan yukarıya doğru kademeli bir daralma görülmektedir. Sülüs hatla yazılmış beş satırlık kitabe kuşağını çevreleyen bir bordürle birlikte, satırları birbirinden ayıran silmeler mevcut değildir. Şahide omuzlarının üstünden başlığa geçişte gövde iç bükey şekilde düz ve dikey bir biçimde keskince pahlanarak daralmaktadır. Pahlı kısmın üzerinde başlık boynuna geçilmeden sağ ve solda iç bükey pahlarla oluşturulmuş mukarnasa benzer ters üçgen süslemeleri ile karşılaşılmaktadır. Ters üçgenlerin üstünde aynı zamanda başlık boynu ile şahide gövdesini ayıran yatay ince bir silme görünmektedir. Silme gövdeyi ön ve arka yüzde daire şeklinde dolanmaktadır. Silmenin üzerinde aşağıdan yukarıya doğru daralan hafif oval şekildeki başlık boynu mevcuttur. ulaşmamıştır.

Başlık: Şahidenin hotoz olması muhtemel başlığı kırık olup günümüze

\section{d-Cücezâde Es-Seyyîd Mehmed Efendi}

Şahide No:5

Ayaktaşı No:2

Başlık No:7

Şahide Çizim No:4

Ayaktaşı Çizim No:2

Sahibi: Es-Seyyîd Mehmed Efendi

Tarihi: H.10 Muharrem 1268/M.14 Kasim 1851

Mezar Formu: Muhtemelen toprak mezar

Şahide Formu: Dikdörtgen kesitli erkek başlıklı 
Ayaktaş1 Formu: Dikdörtgen kesitli sivri kemerli tepelikli

Malzemesi: Mermer

İşleniş Tekniği: Oyma ve kabartma

Kitabe Yazı Türü: Talîk

Kitabe Metni:

El-Bâkî Hüvâllahû-teâlâ

Bir nice müdded Yahya Paşa Cami'

şerîfinin sürûrı ma'nevî

ihyâsına müzâhir olan tefsir-i âyân-ı ilâhiyye ve sîyer-i

âsâr ve ehâdis-i nebeviyye ve tedris-i ulûm-ı ilâhiyye

ve tezkîr-i v'az u nasihât-ı

meâliyye ile meşgûl iken gabn-i kazâ'

ol vechle irtihâl-i dâr-ı bekâ iden merhûm ve măgfûr

Cücezâde Es-Seyyîd Mehmed Efendi

Rûh-ı şerîfleri içün Fâtihat'ül-kitâb

Fî sene 68 garsz (gars) 10 Muharrem

Genel Tanım: Dikdörtgen kesitli erkek başlıklı şahide gövdesini dikdörtgen bir bordür çevrelemektedir. On bir satırdan oluşan talîk hatlı kitabe kuşağı sağdan sola hafif diagonal şekilde yükselmektedir. Aynı durum satırların yerleştirildiği kartuşları birbirinden ayıran kalın yatay silmeler için de geçerlidir. En altta tarih ibaresinin bulunduğu kartuş ise oval olarak şekillendirilmiştir. Şahide omuzlarında mevcut olan dikey pahlarla başlık boynuna geçilmektedir. Pahların üzerinde kısmen mukarnas görünümünde uçları aşağıya doğru dönük küçük üçgen pahlara yer verilerek görünüme estetik kazandırılmak istenmiştir.

Başlık: Kalın ve yukarıda belirtildiği gibi yanlardan hafif pahlı bir boynun üzerinde yer alan başlık oval sarıklı başlık şeklindedir. Sarık dilimleri ise yandan yatay ve üstten çaprazlama olarak birbirlerini kesen baklava dilimleri halindedir. Dilimler başlığın altında ince bir silmede birleşmekte, ince silme başlığ 1 dairevi olarak çevrelemektedir. Başlığın açık bırakılan üst kısmının ortasında bir düğme mevcuttur

Ayaktaşı: Dikdörtgen kesitli sivri kemerli ayaktaşının şahidenin karşısında olması ve fiziksel olarak yakın ölçülerde bulunması dolayısıyla şahideye ait olduğu düşünülmüştür. Yeşile boyanmış ayaktaşının alt kısmındaki boyalar tamamen silinmiştir. Tepelik veya alınlık kısmında yoğunlaşmakla birlikte ayaktaşı gövdesinin diğer yerlerinde de silinmelerle karşılaşılmaktadır Ayaktaşı gövdesinde bitkisel bir süsleme unsuruna yer verilmiştir. İnce bir gövdeden çıkan servi ağacı tepeliğe doğru yükselmekte ve tepesi hafif bir kıvrımla son bulmaktadır. Servi ağacının gövdesi ise taramalı olarak şekillendirilmiştir. Gövdede en altta uçları aşağıya dönük iki ince dalla, hemen üstünde uçları yukarı kıvrık iki kalın dal motifi mevcuttur. Bu dallardan itibaren 
gövde yükselmekte olup gövde üstünde "v" şeklinde sağ ve sola doğru açılan altı adet dal figürü bulunmaktadır.

\section{e-Ahmed Paşa Kethüdâsı Süleyman Ağa}

Şahide No:6

Ayaktaşı No:3

Başlık No:8-9-10

Şahide Çizim No:5

Sahibi: Süleyman Ağa

Tarihi: H.1151/M.1738-1739

Mezar Formu: Muhtemelen toprak mezar

Şahide Formu: Dikdörtgen kesitli erkek başlıklı

Ayaktaşı Formu: Dikdörtgen kesitli sivri tepelikli

Malzemesi: Mermer

İşleniş Tekniği: Oyma ve kabartma

Kitabe Yazı Türü: Sülüs

Kitabe Metni: $\quad$ Ahmed Paşa

\section{Kethüdâsı merhûm}

Süleyman Ă̆a

Rûhu-çün Fâtiha

\section{1}

Genel Tanım: Dikdörtgen kesitli erkek başlıklı şahide fiziksel olarak küçük olup yukarıdan aşağıya doğru hafifçe daralan formdadır. Sülüs hatla yazılmış beş satırlık kitabe kuşağını çevreleyen bir bordür bulunmamaktadır. Aynı durum satırlar için de geçerlidir. Bununla birlikte şahide gövdesinin toprağa gömülü olduğu yerde iç bükey iki yarım daire pahla, şahide gövdesinden boyna geçişte ise bu kısma kademeli bir görüntü veren iç bükey pahlar mevcuttur. Aynı şekilde şahide gövdesinin arka yüzeyi de yanlardan iç bükey şekilde pahlanarak ortada düz bir zemin elde edilmiştir. Ön yüzde, gövdeye kademeli bir görünüm veren pahların bittiği noktada bulunan düz bir silme başlık boynu ile gövdeyi ayırmaktadır. Şahide gövdesi koyu yeşile boyanmıştır.

Başlık: Yeşile boyalı kalın ve oval bir boyun üzerinde bulunan başlık, sarıklı kavuk başlıktır. Başlığ 1 oluşturan kavuk çizgili kavuk türüne girmektedir. Sarık diagonal veya çaprazlama biçimde sarılmış olup, alt ve üstten geçerek çizgili kavuğu çevrelemektedir. Kavuktaki çizgiler oyma tekniği ile yarım daireye benzeyen noktalar halinde ve kesikler şeklinde biçimlendirilmiştir. Kavuğun tepesinde bulunan 
düğmenin etrafında zamanın getirdiği yıpranma nedeniyle net olarak belli olmayan altı adet terk veya dilim mevcuttur.

Ayaktaşı: Şahide karşısında bulunduğu için şahideye ait olduğu düşünülen ayaktaşı şahideyle eşit boyda olup dikdörtgen kesitli sivri tepelikli formdadır. Üzerinde herhangi bir süsleme bulunmayan ayaktaşı, yer yer yıpranmalarla birlikte yeşile boyalıdır.

\section{f-Koca Hüseyinzâde Mehmed Efendi oğlu}

Şahide No:7

Başl1k No:11-12

Şahide Çizim No: 6

Sahibi: Mehmed Efendi oğlu

Tarihi: H.1290/M.1873-1874

Mezar Formu: Muhtemelen toprak mezar

Şahide Formu: Dikdörtgen kesitli erkek başlıklı

Malzemesi: Mermer

İşleniş Tekniği: Oyma ve Kabartma

Kitabe Yazı Türü: Sülüs

Kitabe Metni: $\quad$ Sene 1290

Hüvel-hallâk'ül-bâkî

Değildir kimseye bâkî bu âlem

Mütehakkık serteser fânidir âlem

Kamunın nevbeti gelse gerekdir

Gedâ olsun gerek ise muazzam

Merhûm ve mağfûr Koca Hüseyn

zâde Mehmed Efendinin oğll...

Genel Tanım: Dikdörtgen kesitli erkek başlıklı şahide yeşile boyalı olup, form olarak yukarıdan aşağıya doğru hafifçe daralmaktadır. En alt kısmı kırık olan sülüs hatla sekiz satır olarak yazılmış kitabe kuşağını ince ve dikdörtgen bir bordür çevrelemektedir. Bordür tarih ve serlevhâ ibarelerinin bulunduğu kartuşta yuvarlak veya çan kemer şeklini alarak başlık boynu ile kitabe kuşağını birbirinden ayırmaktadır. Kitabe satırlarının yer aldığı kartuşlar standart bir kalınlıkta olmayan yatay silmelerle bölünmüştür. En üstte, tarih ve serlevhânın bulunduğu kartuşun alt 
silmesi kalın olup, kartuşun yanları ise zikzaklı olarak yapılmıştır. Kartuşta tarih en üste konulmuş olup serlevhâ tarihin altındadır.

Başlık: Yukarıdan aşağıya doğru hafifçe daralan kalın bir boynun üstünden yükselen başlık sarıklı başlıktır. Sarılma şekli sebebiyle paşalı olarak bilinen türe giren başlıktaki sarık ön yüzde ters c şeklinde sarılmış olup arka yüzde düzdür. Sarık aynı zamanda diagonal olarak yükselen kalın dilimlerden oluşmaktadır.

\section{g-Eycelizâde Halîlesi Seyyîde Âişe}

Şahide No:8

Sahibi: Seyyîde Âişe

Tarihi: H.1231/M.1815-1816

Mezar Formu: Muhtemelen toprak mezar

Şahide Formu: Dikdörtgen kesitli muhtemelen kadın başlıklı veya sivri kemerli Malzemesi: Mermer

İşleniş Tekniği: Oyma ve kabartma

Kitabe Yazı Türü: Sülüs

Kitabe Metni: $\quad$ Bu iki seng-i mezâr oldu güvâh

Ben dahi ibretnümâ oldum sana

Dide-i i'mâyla etsen nagâh

Fevtimin tarihidir Vasfi dinür

Âişe gitdi sarây-ı adne vâh

Eycelizâde Osmân Ăganın

Halîlesi Seyyîdet' üs-saâdât

Merhûme ve măgfûre Âişe

Genel Tanım: Dikdörtgen kesitli, muhtemelen kadın başlıklı şahide yukarıdan aşağıya hafifçe daralmaktadır. Sekiz satırdan oluşan sülüs kitabe kuşağını dikdörtgen bir bordür çevrelemekte, yatay şekilde sağdan sola uzanan kitabe satırları benzer şekilde yatay silmelerle birbirinden ayrılmaktadır. Şahide tarihi kitabede ebced hesabıyla yer almaktadır. Tam tarih düşürme yöntemine göre yapılan hesaplamada H.1231/M.1815-16 yılı tespit edilmiştir.

Başlık: Şahidenin başlık kısmı boyunla birlikte tamamen kırılmış olduğundan bu hususta net bir tespit yapılamamıştır. Muhtelemen kırılmadan önce hotoz türü bir kadın başlığı veya süsleme kompozisyonlarına yer verilen sivri kemerli alınlık mevcut olmalidir. 


\section{h-Kara Mehmedzâde Hâfız Âlî Kerîmesi Hûrî Hanım}

Şahide No:9

Sahibi: Hûrî Hanım

Tarihi: H.1326/M.1908

Mezar Formu: Muhtemelen toprak mezar

Şahide Formu: Dikdörtgen kesitli muhtemelen sivri kemerli

Malzemesi: Mermer

İşleniş Tekniği: Oyma ve kabartma

Kitabe Yazı Türü: Sülüs

Kitabe Metni: $\quad 1326$

\section{Hâcı Kara Mehmed \\ zâde Hâfiz Âlî \\ Efendi kerimesi \\ Hûrî Hanım \\ Rûhuna Fâtiha}

Genel Tanım: Dikdörtgen kesitli ve muhtemelen kadın başlıklı olan şahidenin başlık kısmı kırılmıştır. Altı satırdan oluşan ve talîk hatla yazılan kitabe kuşağını çevreleyen bir bordür mevcut değildir. Satırlar yanlardan hafif oval dikdörtgen kartuşlar içinde sağdan sola doğru diagonal olarak yükselmektedir. Sadece en üstte düzensiz küçük bir dikdörtgenin içinde olan tarih ibaresi yatay ve düz olarak şahideye işlenmiştir. Tarih kartuşunun altında bulunan kartuş yatay düzensiz üçgen görünümünde olup, üst silmesi çıkıntılı olarak şekillendirilmiştir. En alttaki kartuşa dua kısmı sıkışık yazıldığından satır zor okunmaktadır. Tarih kısmının bulunduğu kartuşun üzerinden yükselen kısım solda pahlı olup boyun görüntüsü vermektedir. Ancak sağ tarafta bu görüntü ve şekil mevcut değildir. $\mathrm{Bu}$ durumun şahidenin başlığının kırılması ile alakalı olduğu anlaşılmaktadır.

Başlık: Şahide gövdesinin sona erdiği ve tarih ibâresinin yer aldığı boyun kısmından itibaren başlık kısmı kırıktır. Bu sebeple herhangi bir tespit yapılamamıştır.

\section{Sonuç ve Değerlendirmeler}

Nazilli'de Osmanlı döneminden kalma az sayıda eserden birisi olan Yahya Paşa Cami, günümüzde şehrin Aşağı Nazilli olarak adlandırılan bölgesindeki Dumlupınar mahallesinde yer almaktadır. XIX. yüzyılın sonlarında Aydın Demiryolu'nun şehirden geçişiyle gelişmeye başlayan Yukarı Nazilli veya diğer ismiyle Pazarköy'le birlikte, şehrin temel yerleşim merkezini Aşağı Nazilli oluşturmaktadır. Bu nedenle birkaç istisna hariç Osmanlı döneminden kalma eserler burada bulunmaktadır. 
XVI. yüzyılda inşa edilen, mimarisi ve iç mekanındaki süslemeler açısından dikkat çekici yanları olan Yahya Paşa Cami'nin bahçesinde küçük bir hazire mevcuttur. Bu hazire aynı zamanda Nazilli'de günümüze gelmiş nadir örneklerden birisidir. Caminin bulunduğu Dumlupınar mahallesi sakinlerinin verdiği bilgiye göre, bazı taşlar hazireye ait olmayıp buraya sonradan taşınmışlardır. Ancak bu hususta kesin bilgi yoktur.

Caminin kıble yönündeki beden duvarı ile sağ beden duvarının kesiştiği noktada bulunan hazirede üç ayaktaşı ve dokuz şahide olmak üzere toplam on iki Osmanlı dönemine ait mezar taşı mevcuttur. Hazirede bulunan Hâcı Nûrî Efendizâde Mustafâ Efendi'nin mezar taşı ise Latin harfleriyle yazılmıştır. Bu taş herhangi bir süsleme veya form içermediği gibi, günümüzdeki mezar taşlarıyla benzer nitelikte olduğu için incelemeye dahil edilmemiştir. İncelemede yalnızca Osmanlı dönemine ait olan dokuz şahide ve üç ayaktaşı ele alınmıştır. (Tablo-I-II, Resim No:III, VI)

\section{Form ve Süslemeler}

Yahya Paşa Cami haziresinde bulunan mezar taşlarından erkeklere ait olan altı şahide dikdörtgen kesitli ve başlıklı formdadır. (Tablo-I, III-a, III-b, Şahide No: 1, 2, 3, 5, 6, 7) Kadınlara ait olan dikdörtgen kesitli ve kadın başlıklı formlu üç şahidenin başlıkları kırılmıştır. (Tablo-I; Şahide No:4, 8, 9) Hazirede bulunan üç ayaktaşı ise dikdörtgen kesitli ve sivri kemerli olarak şekillendirilmiştir. (Tablo-II; Ayaktaş1 No:1, $2,3)$ Şahide ve ayaktaşı gövdeleri genel olarak yukarıdan aşağıya doğru daralan şekilde biçimlendirilmiştir. Bununla birlikte bir ayaktaşı ile bazı şahide gövdelerinde orta kısımla alt ve üst taraflarda kırılmalar mevcuttur. (Tablo-I-II, Şahide No: 4, 5, 7, 8, 9, Ayaktaşı No:1) Bu sebeple bunlardan birisi olan Koca Hüseyinzâde Mehmed Efendi oğlu isimli kişinin tam kimliği belirlenememiştir. Bazı şahide gövdelerinde gövde ile başlık arasında kalan kısımda, boyunda ve gövdenin toprağa dikildiği noktalarda kısmen mukarnas görünümlü olan iç veya dış bükey pahlar mevcuttur. $\mathrm{Bu}$ sayede görünüme estetik kazandırılmak istenmiştir. (Tablo-I, Şahide No:4, 5, 6)

Şahide gövdelerinde yer alan kitabe kuşağını çevreleyen dikdörtgen bordürler serlevhâ ve tarih kartuşu ile başlık boyunlarını ayırmaktadır. İki şahidede kitabe kuşağını çevreleyen bir bordür yoktur. (Tablo-I, Şahide No: 4, 6) Kitabe kuşağını birbirinden ayıran silmeler ise satırlarla paralel olarak diagonal veya hafif diagonal şekilde yükselmektedir. Hûrî Hanım şahidesinde kitabe satırlarını birbirinden ayıran silmeler en eğimli olanlardır (Tablo-I, Şahide No:9) Dört şahidede silmeler serlevhâ ve kartuşların bulunduğu satırda düzensiz dikdörtgen şeklini almaktadır. Bunlardan Nûrî Efendi ve İbrahim Efendi şahidelerinde serlevhâ ve tarih kısmını başlık boynundan ayıran silmenin kilit taşı noktasında yukarı doğru kaş kemer çıkıntıları mevcuttur. Koca Hüseynzâde Mehmed Efendi oğlu şahidesinde ise bordür silmesi aynı kartuşta başlık boynu ile kitabe kuşağını ince silme halinde yuvarlak veya çan kemer şekline girerek ayırmaktadır. (Tablo-I, Şahide No: 1, 2, 3, 7)

Kitabe kuşağında bordür ve yatay silmelerle oluşturulan kartuşlar dikdörtgen şeklindedir. Yine dört şahidede bu dikdörtgenlerin serlevhâ ve tarih kartuşunda 
düzensiz dikdörtgen olduğu görülmektedir. (Tablo-I,Şahide No: 1, 2, 3, 7) Koca Hüseynzâde Mehmed Efendi oğlu şahidesinde serlevhâ ve tarihin yer aldığı kartuşun yanları zikzaklıdır. Cücezâde Es-Seyyid Mehmed Efendi şahidesinde tarih ve dua ibarelerinin yer aldığı en alttaki kartuş yanları oval şekilde dikdörtgendir. Hûrî Hanım şahidesinde ise kitabenin ilk satırı ucu sola doğru yatay olarak uzanan düzensiz üçgen şeklindedir. Kartuşun üst silmesinde çıkıntılar görülmektedir. Diğer satırlar oyma tekniği ile yapılmış yanları oval olarak şekillendirilmiş dikdörtgen kartuşların içindedir. En üstte tarih kısmının yer aldığı dikdörtgen kartuş, diğer kartuşlardan küçüktür. (Tablo-I, Şahide No: 5, 7, 9)

Kitabelerde kullanılan yazılar açısından şahideler göz önünde bulundurulduğunda, dokuz şahidede talîk ve sülüs olmak üzere iki tür hatta yer verildiği tespit edilmiştir. Bu hat türlerinden en fazla kullanılanının sülüs olduğu görülmektedir. Dokuz şahidede talîk hatta dört (Tablo-I, Şahide No: 1, 2, 3, 5), sülüs hatta beş örnekte yer verilmiştir. (Tablo-I, Şahide No: 4, 6, 7, 8, 9). Şahidelerde kullanılan serlevhâ ibareleri olarak Hüve'l-Bâkî, Hûvallahu-Teâlâ, Hüve'l-Hallâk'ülBâkî gibi formlarla karşılaşılmaktadır. (Tablo-I)

İncelenen örneklerdeki süslemelere gelindiğinde şahide gövdelerinde kartuşlar ve bazı pahlama örnekleri dışında süsleme kompozisyonlarına rastlanmamıştır. Bununla birlikte iki ayaktaşında Osmanlı mezar taşlarında sıkça tercih edilen bitkisel süsleme motiflerinden birisi olan serviye yer verildiği görülmektedir. (Tablo-II; Ayaktaşı No: 1, 2; Ayaktaşı Çizim No: 1-2) Söz konusu ayaktaşlarından Müftizâde Hâcı Nûrî Efendi'ye ait olması kuvvetle muhtemel ayaktaşı gövdesinde servi görünmeyecek derecede silikleşmiştir. (Tablo-II, Ayaktaşı No:1; Ayaktaşı Çizim No:1) Söz konusu ayaktaşı aynı zamanda herhangi bir boya ve süsleme de içermemektedir. Cücezâde Esseyyid Mehmed Efendi'ye ait olduğunu düşündügüumüz yeşile boyalı ayaktaşında yine servi motifi mevcuttur. Servinin gövdesi aşağıya doğru dönük v şeklinde iki ince dalla başlamaktadır. Bu dalların üzerinde uçları bu kez yukarı dönük ve kıvrık yine v şeklinde iki dal daha mevcuttur. Daha sonra tarama ile estetize edilmiş gövdeye geçilmektedir. Ayaktaşının sivri kemerli tepelik kısmına doğru uzamakta olan gövdede $\mathrm{v}$ şeklinde sağa-sola doğru açılan altı dala yer verilmiştir. Tepeliğe gelindiğinde servinin ucunun hafif öne eğik olarak şekillendirildiği görülmektedir. Koca Hüseynzâde Mehmed Efendi oğluna ait olması muhtemel yeşile boyalı ayaktaşı ise herhangi bir süsleme içermemektedir. (Tablo:II, Ayaktaşı No: 2, Ayaktaşı Çizim No:2)

Osmanlı mezar taşı motifleri arasında en çok rastlananlardan birisi olan servi, uzun boyu, firtınalardaki durgunluğu, temizliği, güzel kokusu, yoğun dal ve yapraklarıyla rüzgâr ve diş etkenlere karşı koruyucu niteliği ile bilinmektedir. Servi sembolik olarak yaz kış yeşil kalmasıyla sonsuz hayatı temsil etmekle birlikte bu vurgu yapılırken en çok kullanılan ağaç motifidir. Tepelerinin eğik olarak stilize edilmesi kaynaklarda aynı zamanda sembolik bir atıfla birlikte, zirefkend veya zirefgend tarz olarak nitelendirilmektedir. Zirefkend tarzı sembolik olarak ilahi iradeye teslimiyeti ifade etmektedir. Nitekim Kur'an-1 Kerîm'de Rahman Sûresi'nin altınc1 ayeti olan "Ven-necmi ve şeceru yescûdan" (Yıldızlar ve ağaçlar ona secde etmektedir) ifadesi bu yaklaşımı desteklemektedir. (Oğuz, 2020: 24, 26) 
Şahidelerde mevcut olan tarihler hicrî olup, yedi şahidede açık bir biçimde yazılmışlardır. $\mathrm{Bu}$ tarihler başlıkların altındaki kartuşlarda serlevhâ ibareleri ile birlikte (Tablo-I, Şahide No: 1, 2, 3, 7, 9) ve şahidelerin en alttaki kartuşlarında dua ibareleriyle birlikte yer almaktadır. (Tablo-I, Şahide No: 4, 5, 6) Tarihin kitabenin el alt kartuşunda yazıldığı şahidelerden Cücezâde Es-Seyyîd Mehmed Efendi'ye ait olan örnekte, dua ibaresinin bulunduğu kartuşun altında bulunan tarih kartuşunda " $f$ ì sene 260" ibaresinden sonra "garz" ifadesi, bu ifadenin altında ise "10 Muharrem" tarihi görülmektedir. Fakat, kelimenin yanlış yazıldığı, doğrusunun "gars" (dikilme) olacağı, bu bakımdan 10 Muharrem tarihinin şahidenin dikildiği tarihi işaret ettiği düşünülmüştür. (Tablo-I; Şahide No:5)

Hazirede bulunan şahidelerde tarihin açıkça yer almadığı yalnızca bir örnek bulunmaktadır. Eycelizâde Osmân Ağa eşi Seyyîde Âişe'ye ait bu şahidede tarih "Fevtimin târihidir Vasfî dinür/ Âişe gitdi sarây-l adne vâh" dizeleriyle Vasfî isimli şair tarafindan ebced hesabıyla verilmiştir. (Tablo-I, Şahide No:8) Osmanlı medeniyetinde kitabe ve şiirlerde sıkça görülen ebced hesabıyla tarih düşürme esasen dolaylı ve edebi bir yönden herhangi bir tarihi Arapça harflere rakamların verilmesiyle işaret etme yöntemine verilen isimdir. Bu şekilde yapılan tarih düşürme veya belirtme, tam, muc'em ve mühmel olmak üzere üç şekilde yapılmaktadır. Tarih mısrasını teşkil eden bütün harflerin ebced hesabındaki sayı kıymetleri hesaba alınırsa verilen tarih tam tarihtir. Yalnız noktalı harflerin sayı değerleri hesaplanırsa, mu'cem, sadece noktasız harfler hesaplanırsa ise belirtilen tarih mühmel tarih kategorisine girmektedir. $\mathrm{Bu}$ doğrultuda şair, hangi tür ebced hesabını kullanmışsa bu durumu son veya sondan bir önceki beyitte açıkça ifade etmektedir. Tarih çeşitlerinden hiçbiri tarih mısrasında zikredilmemişse bu tam tarih uygulamasının kullanıldığının bir göstergesidir (Elker,1956:19-20) Nitekim Seyyîde Âişe örneğinde, ebced hesabıyla düşülen tarihte söz konusu türlerden herhangi birinden bahsedilmemesi, düşülen tarihin tam tarih olduğunu göstermektedir. Yapılan hesaplamada ise Seyyîde Âişe'nin vefat tarihinin H.1231/M.1815-1816 y1lı olduğu tespit edilmiştir.

\section{Başlıklar}

Yahya Paşa haziresi mezar taşlarında yalnızca erkeklere ait şahidelerde başlıklara rastlanmış olup, kadınlara ait üç şahidedeki başlık veya alınlığa rastlanmamıştır. Haziredeki erkek başlıkları, sarıklı oval başlık, sarıklı fes başlık ve sarıklı kavuk başlıklardan ibarettir. (Tablo: III-a,III-b; Şahide No:4, 8, 9; Şahide Çizim No: 1, 2, 4, 5; Başlık Çizim No: 1, 2, 3)

Türkçe sarmak kökünden gelen sarığın Farsçadaki karşılığı destâr, Arapçadaki karşılığ 1 ise ammame veya emamedir. Erkekler tarafından kullanılan bir giyim eşyası olan sarık bir kavuk veya fesin etrafina sarılan bez veya tülbenti tanımlamaktadır. Osmanlılarda festen önce giyilen bütün kavuklarda sarık kullanıldığından, kavuk ve sarık esasen aynı anlama işaret etmektedir. Kavuklar ise üzerlerindeki sarığın sarılış biçimi, rengi ve görüntüsüne nazaran isimlendirilerek çeşitlendirilmekte olup, Osmanlı mezar taşlarında en çok rastlanan başlıklar arasındadır. (Gökler-Köşklü, 2019: 453-454) 
Osmanlı mezar taşlarında XVII. yüzyılın sonlarında daha çok görülmeye başlanan kavuklar, dış yüzleri çuhadan yapılma, içleri astar bez ile kaplı, arasına pamuk konulan ve üzerinde farklı türde dikimler yapılan bir başlık türüdür. XV-XVII. yüzyıllar arasına ait mezar taşlarında üzerine sarık sarılan kavuklar genellikle ya hiç görülmemekte veya sadece tepeleri görünmektedir. XVII- XIX. yüzyıllara ait mezar taşı başl1klarında ise kavuklar büyük ölçüde görünür hale gelmiştir. (Aslan, 2007: 462)

XIX. yüzyılın ilk yarısından itibaren Osmanlı mezar taşı başlıklarında görülen diğer başlık türü feslerdir. Fes esasen Kuzey Afrika'da Fas şehrinde icat edildiği için bu isimle anılan kırmızı renkli bir başlık olup, 1827-1925 tarihleri arasında kullanılmıştır. Fesin başı kapsayan kısmının üstüne tabla denir. Bu tablanın ortası delik olup bu deliğe 2,25 santim boyunda ibik denilen bir parça eklenir. Püskül ise söz konusu ibik vasıtası ile takılır. İlk defa II. Mahmud döneminde kullanılan ve bu döneme atıfla Mahmudiye-Mahmudî ismiyle anılan fesler, şeklen büyük ve yüksek olup, püskülleri mavi ipektendi. Sultan Abdülmecid döneminde fes küçülerek son zamanlara kadar kullanılan temel şeklini almıştı. Püskülle ipek yerine burma ibrişimden yapılmaya başlanmıştı. Sultan Abdülaziz zamanında fesin kalıbı yine değişmiş ve Azîziye veya Azîzî olarak adlandırılan fes tipi ortaya çıkmıştır. Ancak Abdülhamid döneminde bu kez padişaha nisbeten Hamîdî olarak adlandırılan kalıp türe geçilmiş, yayvan kalıplı Azîziye modeli terkedilmişti. (Koçu, 2015: 119, 121)

Yahya Paşa haziresinde tespit edilen başlıklarda ilk türü sarıklı oval başlık olarak kategorize edilen tiptir. Bu tipte başlığın yapısı oval olup, sarık, takke türü bir iç başlı̆̆ın dışında iri dilimlidir. Bu tür XVIII-XX. yüzyıllar arasında görülmektedir. (Çal, 2015: 312) Müftizâde Hâcı Nûrî Efendi'ye ait oval biçimli başlık sarıklı oval başlık sınıfına girmektedir. Başlık üzerindeki sarığın dilimlerinin diagonal olarak sağdan sola yükseldiği görülmektedir. Kalın bir dilim sarığı ortadan ikiye ayırmaktadır. (Tablo-I; Şahide No: 1, Başlık No:1) Aynı tipte kabul ettiğimiz Cücezâde Es-Seyyid Mehmed Efendi'ye ait başlıkta ise tepe kısmı Hâcı Nûrî Efendi örneği gibi boş bırakılmış olup sarık baklava dilimi şeklinde çaprazlama geçecek şekilde sarılmıştır. (Tablo-I, III-a, III-b, Şahide No:5, Başlık No:7, Şahide Çizim No:4)

Mehmed Salih Efendi ve Hâcı Kara Mehmedzâde İbrâhim Efendi şahidelerindeki başlıklara gelindiğinde ise bunların sarıklı-fes başlık kategorisine girdiği görülmektedir. Bu tipte sarık, fes tipi bir başlığın sadece tepesi görünecek şekilde dilimlerle sarılması ile oluşmuştur. Ortada enli bir çapraz dilim mevcuttur. İki alt tipi olan sarıklı fes başlığın ilk alt tipinde başlık fes olursa tepe düz olmaktadır. (Çal, 2015: 312; Tablo- I, Şahide No:2-3, Başlık No:2-6, Şahide Çizim No: 1, 2, Başlık Çizim No:1-3)

$\mathrm{Bu}$ tipe giren Mehmed Sâlih Efendi şahidesindeki başlıkta fes başlığın çevresini çaprazlama olarak uzanan bir sarık çevrelemektedir. Dilimlerden ortadaki diğerlerine nazaran daha büyük olup, ön yüzdeki dilimleri ikiye ayırmaktadır. Arka yüzde ise dilimler tek bir biçimde olup ortada birleşmektedir. (Tablo-I, Şahide No:2, Başlık No: 2, 3; Şahide Çizim No: 1, Başlık Çizim No:1) Hâcı Kara Mehmedzâde İbrâhim Efendi şahidesindeki fes başlığı çevreleyen sarık ise, üstten ince ve kısmen görülecek şekilde, alttan ise kalın ve başlığın büyük bir bölümünü kaplayarak şekilde 
çevrelemektedir. Başlık ön yüzünün tablasının bir kısmının kırık olduğu görülmektedir. Fes tablasının ortasındaki püskül üstteki ince sarık diliminin içine yerleştirilmiş ve böylece arka yüzde ön yüze nazaran daha estetik bir görünüm elde edilmiştir. Fes başlığ 1 çevreleyen sarık dilimlerinin üzerinde diagonal şekilde işlenmiş dört yapraklı çiçek ve üçgen yaprak motifleri görülmektedir. (Tablo-I, Şahide No:3, Başlık No:4, 5, 6; Şahide Çizim No: 2, Başlık Çizim No: 2, 3)

Yahya Paşa haziresinde sarık ve fesli başlıklarla birlikte karşılaşılan üçüncü tip başlık sarıklı kavuk başlıklardır. Bu başlıklar Süleyman Ağa ile Koca Hüseyinzâde Mehmed Efendi oğluna aittir. Bunlardan Süleyman Ağa başlığında sarığın çaprazlama sarılmış dilimleri ön ve arka yüzde diagonal bir biçimde kavuk başlığ çevrelemektedir. ${ }^{3}$ (Tablo-I, Şahide No:6, Başlık No, 8-10, Şahide Çizim No: 5)

$\mathrm{Bu}$ başlık türlerinde genel olarak baklava dilimli kavukların etrafi kalın ve eğimli sarık dilimleri ile sarılıdır. Dilimler birbirlerinin alt ve üstünden çaprazlama şekilde geçmektedir. Bu başlıklar Larequr tarafından İstanbul'da en çok görülen türleri arasında sayılmakta ve yedi versiyonundan bahsedilmektedir. Larequr'a göre erkek başlık türleri arasında en kolay yapılabilenler bu sınıftadır. Süleyman Ağa şahidesine ait başlık, Larequr tarafından E-IV olarak numaralandırılan bu tipe dahil edilebilir. Bu tipte başlık daha yüksek ve tepe bölümü yuvarlaktır. (Larequeur, 1997:147)

Süleyman Ağa şahidesinin hemen yanında bulunan Koca Hüseyinzâde Mehmed Efendi oğlu adlı şahide sahibinin başlıktaki sarığın ön yüzde paşalı kavuk olarak belirlenen tipte görülen şekilde sarılmış olduğu görülmektedir. Yeşile boyalı başlıkta ön yüzde sarık sağ ve solda çaprazlama dilimler halinde sarılmıştır. Arka yüzde ise bu şekillendirme görülmeyip sarık düz olarak sarılmıştır. Ön yüzde sarığın sarılma şekli başlığın alt kısmına ters c veya $\mathrm{v}$ harfine benzeyen oval bir şekil vermektedir ki, bu şekil paşalı kavuklarda görülen şekildir. (Tablo- I, Şahide No: 7, Başlık No:11-12, Şahide Çizim No: 6)

Katibî kavukların dokuz türünden birisi olan paşalı kavuklar fesin gelişine kadar kullanılmıştır. Bu başlıkta, önde kavuk ve üzerine lamelif şeklinde yani çaprazlama sarılan destar bulunmaktadır. Paşalı kavuklar kafesli çubuklu, sade ve çizgili tiplerde dağılım göstermektedir. Paşa rütbesine sahip kişilerde rastlanan bu başlık türü, hattat, kapıağası, saray mutfağındaki hizmetliler ve mehterân mensupları gibi farklı sınıflarca da tercih edilmişti. (Ökçesiz, 2013: 94; Gökler-Köşklü, 2019: 458)

\section{Kimlik}

Yahya Paşa haziresindeki mevcut şahideler kimlik açısından göz önünde bulundurulduğunda altısının erkeklere (Tablo-I, Şahide No:1-7) üçünün kadınlara ait oldukları görülmektedir. (Tablo-I, Şahide No: 4, 8, 9) Kadın şahide sahipleri arasındaki Hûrî Hanım'ın çocuk olduğu anlaşılmaktadır. Nitekim Osmanlı mezar taşı

\footnotetext{
${ }^{3}$ Süleyman Ağa başlı̆ının şahide gövdesine ters şekilde yerleştirilmiş olması kuvvetle muhtemeldir. Bu durum aynı zamanda başlığın başka bir şahideye ait olabileceği düşüncesini akla getirmektedir. Ancak yapılan incelemede herhangi bir değişikliğe gidilmemiş ve başlık ilk tespit edildiği şekilde ele alınmıştır. (Başlık No: 8-9; Tablo-III-b)
} 
kitabelerinde yaşı ne kadar küçük olursa olsun kız çocuklarına estetik bir tarzda hanım olarak hitap eden örnekler görülmektedir. Ayrıca, çocuk mezar taşları diğerlerine göre kısa ve dar biçimde şekillendirilmekte, kitabe ve mısralar alabildiğince kısa tutulmaktadır. (Samsakçı, 2017: 149, 152, 160).

Yahya Paşa Cami haziresindeki şahidelerde Müftizâde, Hâcl Kara Mehmedzâde, Koca Hüseynzâde, Âlî Ăgazâde, Cücezâde ve Eycelizâde gibi aile, yakın ve akraba isimleri tespit edilmiştir. Bu ailelere mensup şahide sahipleri arasında baba, oğul, erkek kardeş, kız ve eş gibi çeşitli ailevî yakınlıklar mevcuttur. Herhangi bir yakınlık durumu kaydedilmeyen Süleyman Ağa ise, şahidesinde I. Mahmud dönemi sadrazamlarından Şehlâ Ahmed Paşa'nın kethüdası olarak anılmıştır. (Tablo-I, Şahide No:6)

İncelemeye dahil etmediğimiz Latin harfli kitabesine göre Hâcı Nurî Efendizâde Mustafâ Efendi H.1270/M.1853-1854 tarihinde doğup, H.1338/M.19191920 tarihinde vefat etmiştir. Diğer şahideler göz önünde bulundurulduğunda, Hâc1 Nûrîzâde Mustafâ Efendi ile Mehmed Sâlih Efendi'nin kardeş oldukları, babalarının Hâcı Nûrî Efendi olduğu anlaşılmaktadır. Nitekim bu üç isme ait taşlar yan yanadır. Şahidelerdeki tarihlerden hareket edildiğinde, Hâcı Nûrî Efendi'nin vefatından bir yıl önce oğlu Mehmed Sâlih Efendi'nin, on bir yıl sonra diğer oğlu Mustafâ Efendi'nin vefat ettiğini söyleyebiliriz. Şahidelerden tespit edilen isimler arasında aynı aileden olmaları kuvvetle muhtemel diğer şahıslar Hâcı Kara Mehmedzâde İbrâhim Efendi ile Hûrî Hanım'ın babası Hâcı Kara Mehmedzâde Hâfız Âli'dir. (Tablo-I, Şahide No:1, 2 3, 9, Resim No:VI)

Haziredeki şahide sahipleri meslekleri açısından değerlendirildiğinde, müderris, hattat, vaiz gibi daha ziyade ilmiye mensubu şahıslar oldukları görülmektedir. Bunlardan müderris Müftizâde Hâcı Nûrî Efendi'den şahidesinde "ulemâ-yı benâm" ifadesiyle bahsedilmektedir. H.1321/M.1903-1904 tarihli Maârif Sâlnâmesi'ne göre Hâcı Nûrî Efendi Yahya Paşa Cami Medresesi'nde görev yapmakta olup bu tarihte medresede yedi talebe bulunmaktayd1. (Sâlnâme-i Nezâret-i Maârif-i Umûmiye, 1321:376) Medrese ise yukarıda vurgulandığı gibi caminin bahçesinde olup, günümüzde son cemaat yerinin kuzeybatısında kalan geniş bahçe içinde temel kalıntıları mevcuttur. (Tablo-I, Şahide No:1)

Kara Mehmedzâde İbrâhim Efendi'nin ise "hattât- $l$ şehr” sıfatını taşıdığı " $b u$ devr içre muhterem" ibaresiyle sanatıyla Nazilli'de tanınan ve itibar sahibi bir kişi olduğu kitabesinde vurgulanmaktadır. (Şahide No:3) Diğer bir ilmiye mensubu olan Cücezâde Es-Seyyîd Mehmed Efendi'nin görevi ve kimliği şahide kitabesindeki detaylı biçimde belirtilmektedir. Kitabesine göre Es-Seyyîd Mehmed Efendi'nin Yahya Paşa Cami'nde verdiği vaazlarla tanındığı, aynı zamanda tefsir, hadis ve sîyer gibi ilimlerle meşgul ilmiye mensubu bir şahıs olduğu anlaşılmaktadır. (Tablo-I, Şahide No:5)

Hazirede şahidesi mevcut olan kadınlardan Âişe'nin taşıdığı Seyyîde unvanının yanı sıra kitabesinin bir şair tarafından hazırlanması ve ebcedli tarih düşülmesi dikkat çekicidir. Bu durum, Seyyîde Âişe ve ailesinin sosyal statüsünün göstergesi olarak kabul edilebilir. (Samsakçı, 2015: 232) Bununla birlikte eşi 
Eycelizâde Osman Ağa'nın Nazilli'nin ileri gelen ailelerinden Eycelizâde ailesine mensup olduğu görülmektedir. Bu durum, aynı zamanda toplumda statü sahibi aileler arasında yapılan evliliklere bir örnek olarak gösterilebilir. Yahya Paşa Cami'nin hemen üst tarafında kalan Ağa Cami için aynı aileden Eycelizâde ailesi mensuplarından Hasan Ağa bir vakfiye düzenlemiştir. 1873 yılının Mart ayı ile1874 yılının Şubat ayı arasında yapılan muhasebesine göre vakfın mütevellisi aynı aileden olan Nazilli ileri gelenlerinden Hâcı Osmân Bey'dir. Hâcı Osmân Bey’in oğlu Mehmed Emîn'in şahidesi ise Ağa Cami bodrumunda bulunmaktadır. ${ }^{4}$

Yahya Paşa Cami haziresinde I. Mahmûd devri sadrazamlarından Şehlâ Ahmed Paşa'nın Aydın muhassılı iken maiyetinde olduğu anlaşılan Süleyman Ağa'nın şahidesinin mevcudiyeti dikkat çekici bir durumdur. Aslen Alanyalı olan Şehlâ Ahmed Paşa, amcası Ebubekir Paşa'nın yanında yetiştikten sonra 1738 tarihinde Aydın Muhassılı olarak tayin edilmiş ve yörede oldukça etkili olan Sarıbeyoğlu isyanını bastırmakla görevlendirilmişti. Bu görevini takiben İstanbul'a dönmüş, önce nişanc1lığa, 1740 tarihinde ise sadrazamlığa getirilmişti. (Emecen, 1989:114)

Osmanlı arşivindeki belgelerden tespit edildiği kadarıyla Süleyman Ağa Şehlâ Ahmed Paşa'nın ev kethüdâlığı vazifesini yerine getirmekteydi. Sultan I. Mahmud sadaret kaymakamına gönderdiği H.2 Safer 1168/M.17 Kasım 1854 tarihli bir hatt-1 hümâyûnda eski sadrazam Ahmed Paşa'nın oğullarının, Çavuşzâde isimli bir kişinin ve Süleyman Ağa'nın müzayede ile aldıkları malikânelerin ${ }^{5}$ beyt'ül-mâle yani devlet hazinesine geri alınması dolayısıyla yeniden müzayedeye çıkarılması emrini vermişti. Diğer bir hattında ise padişah Süleyman Ağa ile Çavuşzâde'nin hıyanetlerinin bilindiğini, bu sebeple mal, mülk ve eşyalarının zapt edilerek satılmasını, satıştan elde edilen gelirin sefer masrafları için harcanmasını vurgulamıştı. (BOA. TS.MA.e...808/68)

Yukarıda bahsedilen hatla birlikte Sultan I. Mahmud sadaret kaymakamına (sadrazam vekili) gönderdiği başka bir hatta ise Şehlâ Ahmed Paşa kethüdası Mustafâ Ağa'nın sorgulanmasını, nitekim Mustafâ Ağa'nın paşanın ev kethüdası olan Süleyman Ağa ve Çavuşzâde ile birlikte rüşvet işine karıştığı belirtmektedir. (BOA.TS.MA.e...808/68) Bu ifadelerden Süleyman Ăga'nın söz konusu malikane tasarrufu ile birlikte başkent tarafindan hoş karşılanmayan bazı faaliyetlerde bulunduğu anlaşılmaktadır. Vefat tarihi ise Şehlâ Ahmed Paşa'nın Aydın Muhassılı olarak tayin edildiği H.1151/M.1738-1739 yılıdır. ${ }^{6}$

\footnotetext{
${ }^{4}$ BOA.EV.d.22300/6; Sâlnâme-i Vilâyet-i Aydın 1308 Defa-13, C.I, s.157, Salnâme-i Vilâyet-i Aydın 1311, Def'a-14 s.313, Sâlname-i Vilâyet-i Aydın,1323 Def'a-23, s.231.

${ }^{5}$ Malikâne devlete ait bir vergiyi toplama hakkının hayat boyu olmak şartıyla yapılan açık artırmada en yüksek meblağı veren kişiye bırakıldığı uygulamadır. Genç, 2003: 516.

${ }^{6}$ Süleyman Ağa'nın ne sebeple ve ne şekilde vefat ettiği, Ahmet Paşa maiyetinde ev kethüdası vazifesinde iken Aydın ve Nazilli civarında ne tür faaliyetlerde bulunduğu ayrı bir araştırmanın konusu olduğu için bu incelemede yüzeysel olarak değinilmiştir.
} 
ESOGÜ TARİH DERGİSI

Cilt: 4, Sayı:1, 2021, $38-74$

\section{Kaynakça}

Arşiv Belgeleri

Devlet Arşivleri Başkanlığı Osmanlı Arşivi (BOA)

TS.MA.e... (Topkapı Sarayı Müzesi Arşivi Evrakı)

Nr.808/68.

EV.d...(Evkaf Defterleri)

Nr. 22300

\section{Kitap Makale ve Tezler}

Aslan, Ayşegül, Edirne Ü̧̧ Şerefeli Camii Haziresi Mezar Taşları, Gazi Üniversitesi, Sosyal Bilimler Enstitüsü Yüksek Lisans Tezi, Ankara, 2007.

Aydın İl Kültür Müdürlüğ̈̈ Envanteri-I, İl Kültür ve Turizm Müdürlüğü Yayınları, Aydın, 2012.

Çal, Halit, “İstanbul Eyüp’teki Erkek Mezartaşlarında Başlıklar”, Tarihi, Kültür ve Sanatıyla III. Eyüp Sultan Seтроzуити-Tebliğler, İstanbul, 1999, ss.206-225.

“Türklerde Mezar-Mezartaşları” Aile Yazıları-8, Ankara, 2015, ss.295-333.

Elker, Salahaddin, "Kitabelerde Ebced Hesabının Rolü”, Vakıflar Dergisi-III: Ankara, 1956, ss.17-25.

Sâlnâme-i Nezâret-i Maârif-i Umûmiye, Asr Matbaası, İstanbul, 1321.

Emecen, Feridun, "Şehla Ahmed Paşa" İslam Ansiklopedisi, C.2, Türkiye Diyanet Vakfı Yayınlar, İstanbul, 1998, s.114.

Genç, Mehmet, İslam Ansiklopedisi, C.17, İstanbul, Türkiye Diyanet Vakfi Yayınları, İstanbul, 2003, ss.516-518.

Gökler, Burak Muhammed- Köşklü, Zerrin, "Balıkesir Zağanos Paşa Camii Haziresindeki Kavuk Tipleri”, Atatürk Üniversitesi Türkiyat Araștırmaları Dergisi-TAED, 66, Erzurum, 2019, ss.453-478.

Koçu, Reşat Ekrem, Türk Giyim Kuşam ve Süslenme Sözlüğ̈̈, Doğan Kitap, İstanbul, 2015.

Sâlnâme-i Vilâyet-i Aydın 1308 Defa-13, C.I, Vilâyet Matbaası, İzmir, 1308

Salnâme-i Vilâyet-i Aydın 1311, Def'a-14, Vilâyet Matbaası, İzmir, 1311

Sâlname-i Vilâyet-i Aydın, 1323 Def'a-23, Vilâyet Matbaası, İzmir, 1323,

Samsakçı, Mehmet, Ölüme Açılan Estetik Kapı, Kitabevi Yayınları, İstanbul, 2017.

Oğuz, Burhan, Mezartaşlarında Simgeleşen İnançlar, AAV. Yayınları, İstanbul, 2002.

Ökçesiz, Mahmut, Kuşadası Adalızade Osmanlı Mezar Taşları, Kitap Matbaacılık, İstanbul, 2013.

Türkiye'de Vakıf Abideleri ve Eski Eserler, Vakıflar Genel Müdürlüğü Yayınları, Ankara, 1963.

Yurtsal, Tuğçe, Aydın ve Denizli Camilerinde Duvar Resimleri, Gazi Üniversitesi Yüksek Lisans Tezi, Ankara, 2009. 


\section{TABLOLAR}

Tablo-I/ Yahya Paşa Cami Haziresi Şahide Sahipleri

\begin{tabular}{|c|c|c|c|}
\hline Şahide Sahibinin İsmi & Aile İsmi & Şahide Tarihi & Meslek-Ünvan \\
\hline Hâcı Nûrî Efendi & Müftizâde & 8 Cemâziyülevvel 1327/ 28 Mayıs 1909 & Müderris \\
\hline Mehmed Sâlih Efendi & Müftizâde & 24 Zilka'de 1326/18 Aralık 1908 & Hattât \\
\hline İbrâhim Efendi & Hâcı Kara Mehmedzâde & 30 Haziran 1323/ 13 Temmuz 1907 & - \\
\hline Fâtma Kadın & Âlî Ağazâde & $1159 / 1746-1747$ & Müderris-Vâiz \\
\hline Es-Seyyîd Mehmed Efendi & Cücezâde & 10 Muharrem 1268/14 Kasım 1851 & Kethüdâ \\
\hline Süleyman Ağa & - & $1151 / 1738-1739$ & - \\
\hline Mehmed Efendi oğlu & Koca Hüseynzâde & $1290 / 1873-1874$ & - \\
\hline Seyyîde Âişe & Eycelizâde & $1231 / 1815-1816$ & - \\
\hline Hûrî Hanım & Hâcı Kara Mehmedzâde & $1326 / 1908-1909$ & \\
\hline
\end{tabular}

Tablo-II/ Şahide Sahibinin Yakınları

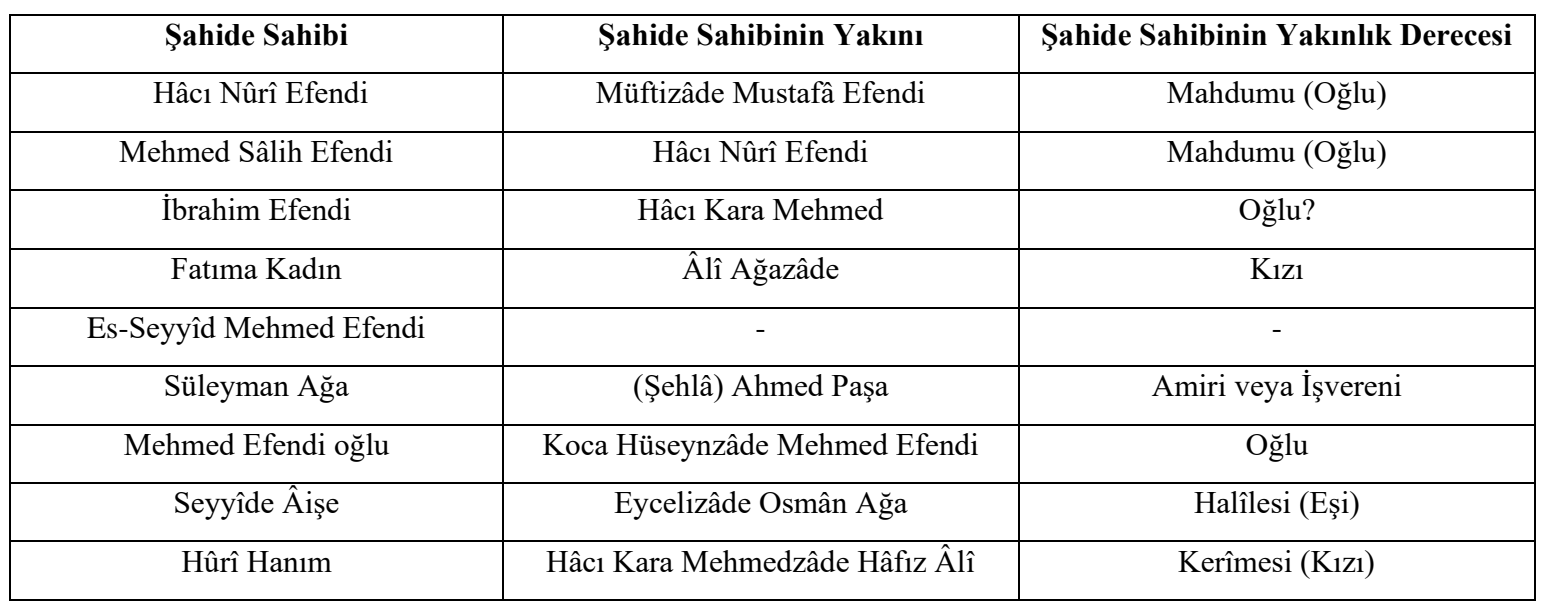


ESOGÜ TARİH DERGISII

Cilt: 4, Sayı:1, 2021, 38 - 74

Tablo-I /Yahya Paşa Camii Haziresi Şahideler

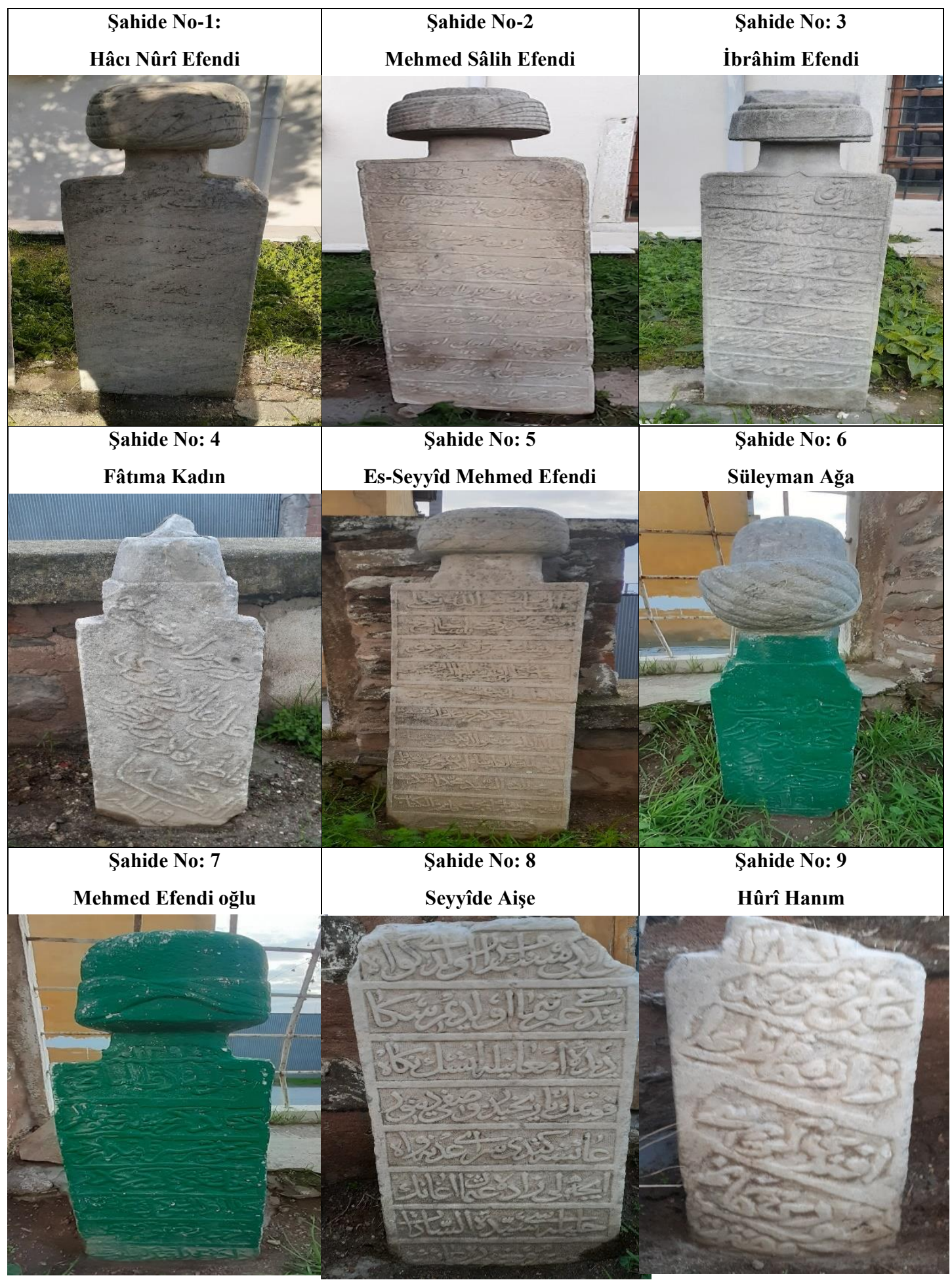


Tablo-II/Yahya Paşa Cami Haziresi Ayaktaşları

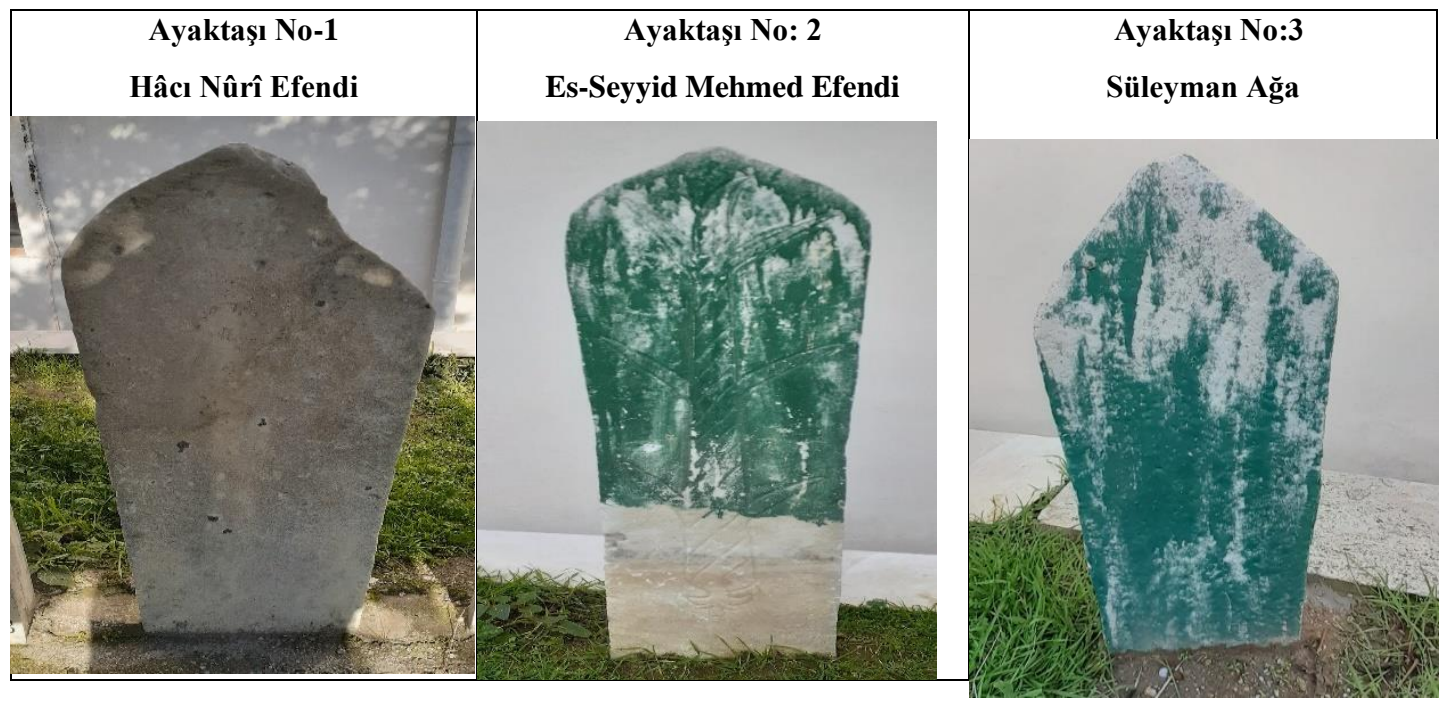

Tablo-III-a/ Yahya Paşa Haziresi Başlıklar

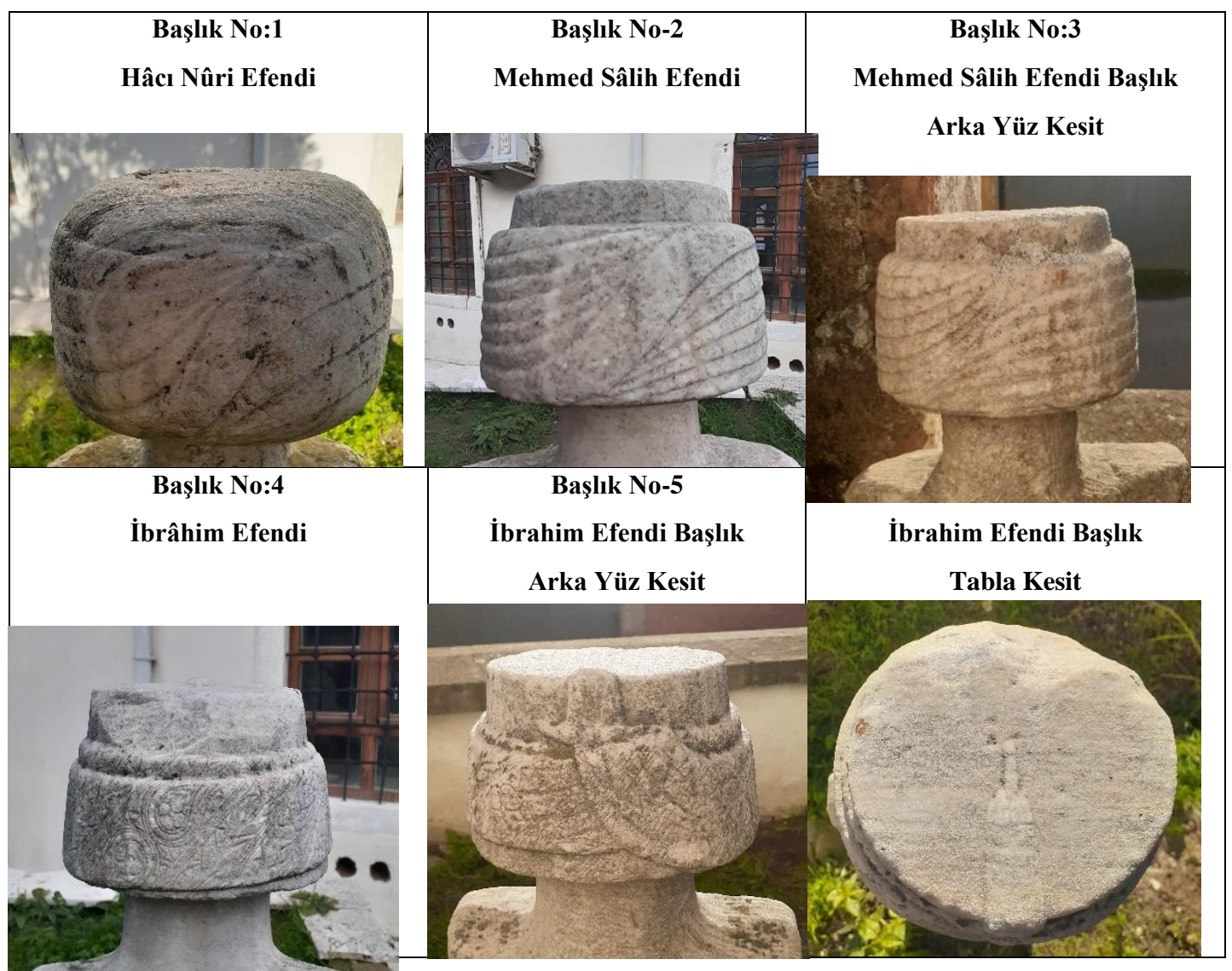


ESOGÜ TARİH DERGISII

Cilt: 4, Sayı:1, 2021, 38 - 74

Tablo-III-b/ Yahya Paşa Haziresi Başlıklar

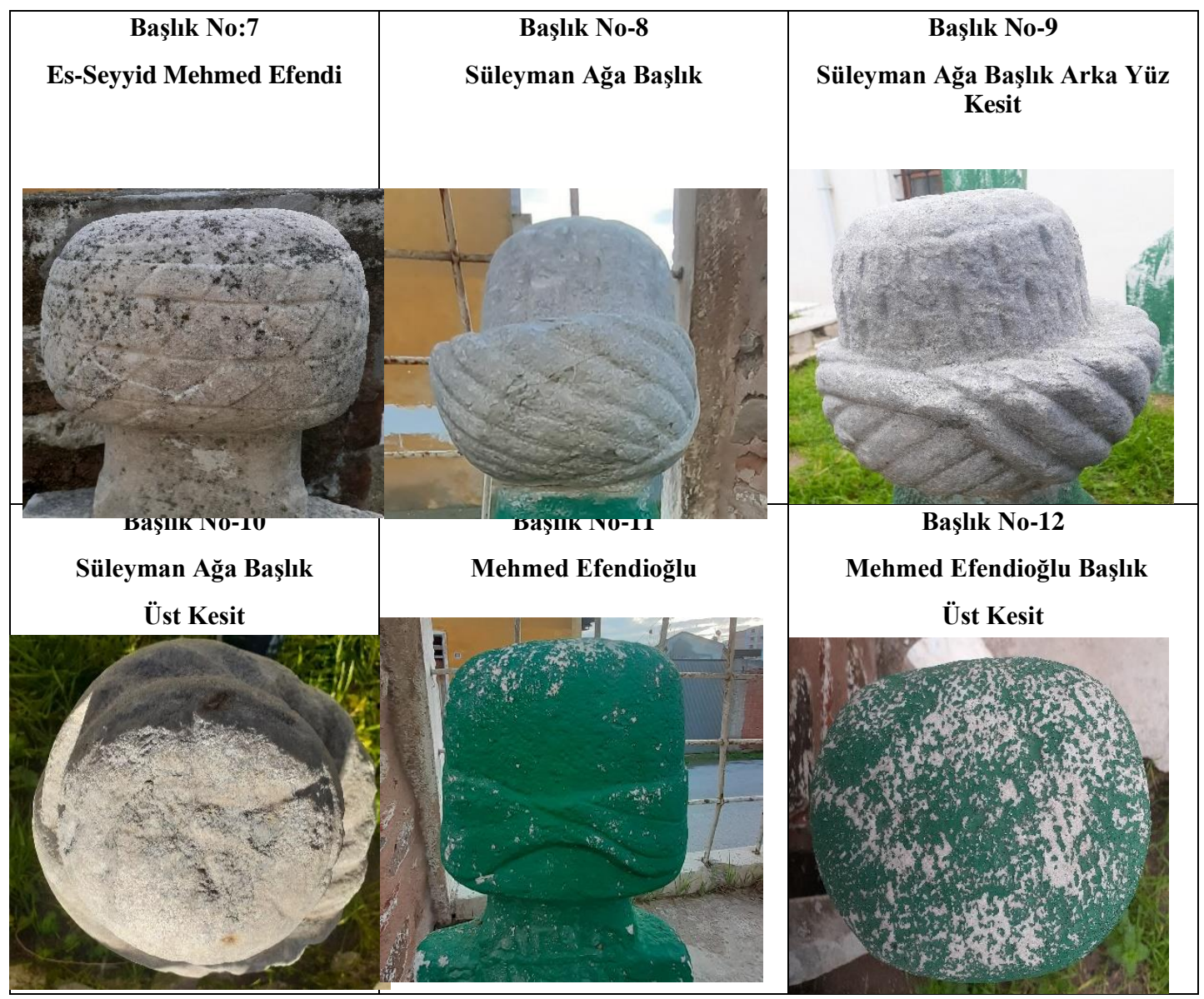


ESOGÜ TARİH DERGİSİ

Cilt: 4, Sayı:1, 2021, $38-74$

\section{ÇİİMLER}

Şahide Çizim No:1/ Hâc1 Nûrî Mahdûmu

Mehmed Sâlih Efendi

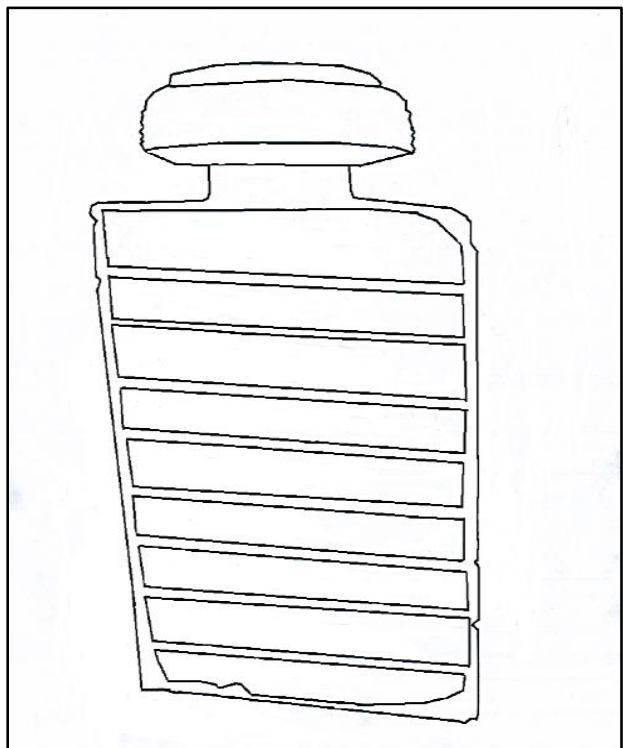

Şahide Çizim No: 2/ Hâcı Kara Mehmedzâde İbrâhim Efendi

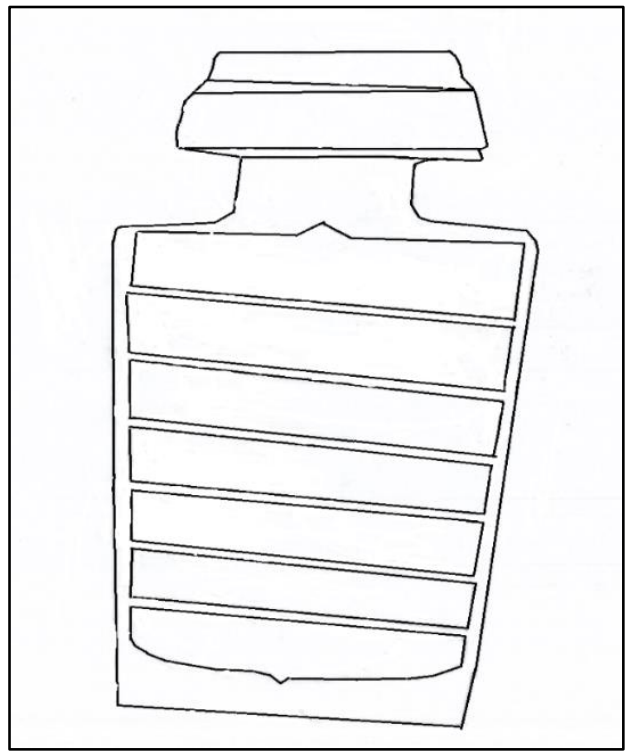


ESOGÜ TARİH DERGISII

Cilt: 4, Sayı:1, 2021, 38 - 74

Şahide Çizim No: 3/Ali Ağazâde

Fatma Kadın

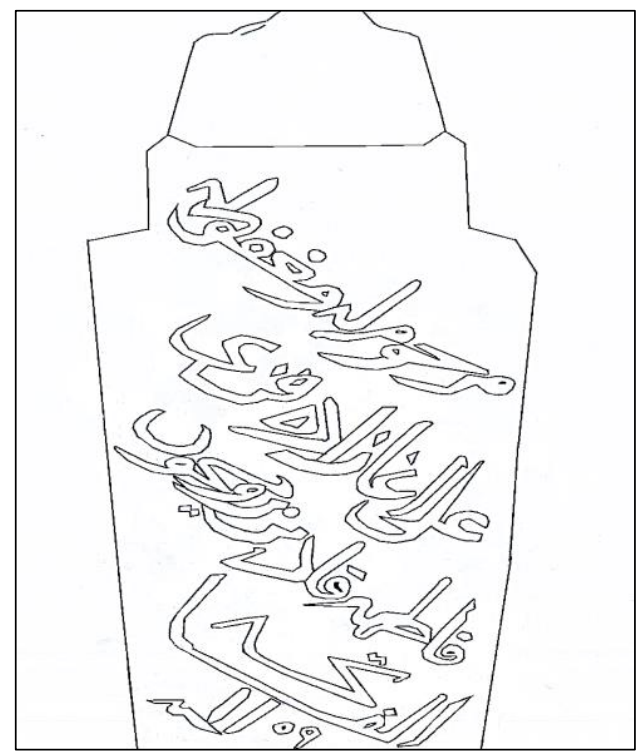

Sahide Cizim No: 4/

Cücezade Es-Seyyid Mehmed Efendi

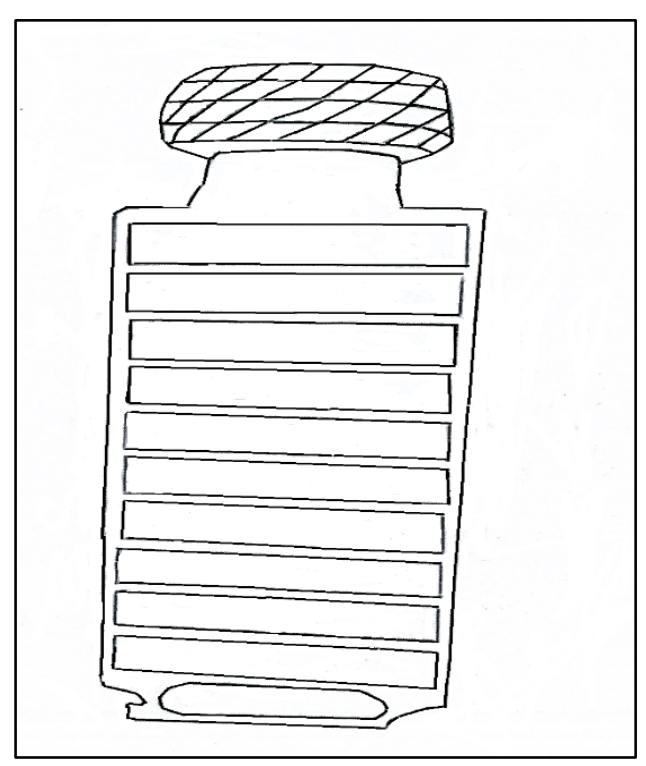


ESOGÜ TARİH DERGISII

Cilt: 4, Sayı:1, 2021, $38-74$

Şahide Çizim No: 5/ Şehlâ Ahmed Paşa

Kethüdâsı Süleyman Ağa

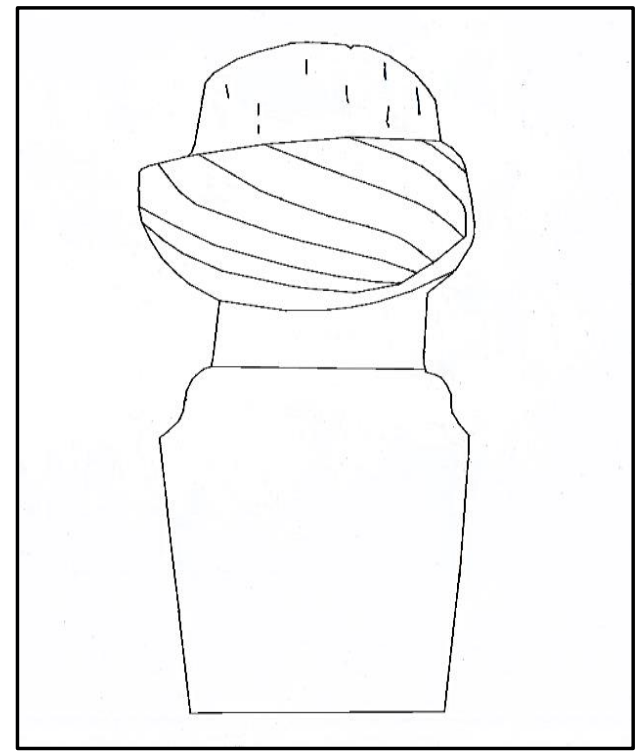

Şahide Çizim No:6/Koca Hüseyinzâde

Mehmed Efendi oğlu

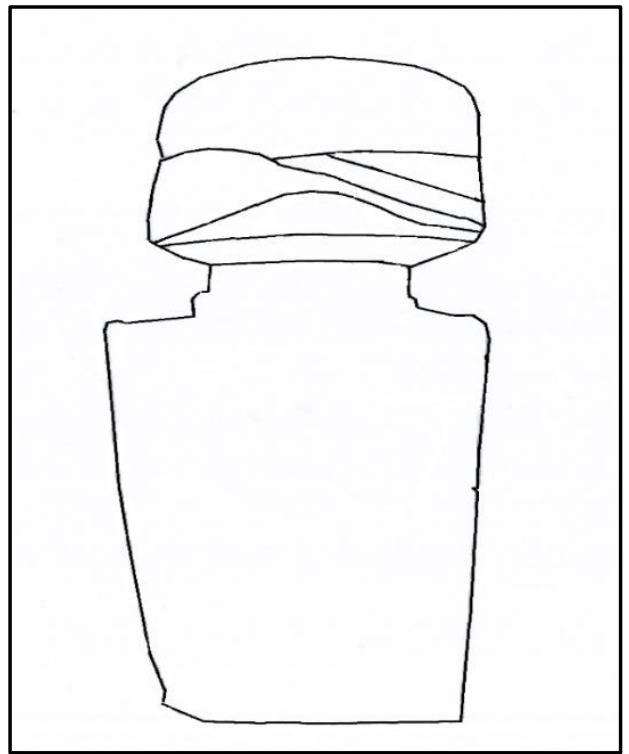


ESOGÜ TARİH DERGİSI

Cilt: 4, Sayı:1, 2021, $38-74$

Ayaktaşı Çizim No:1/ Müftizâde

Hâcı Nûrî Efendi

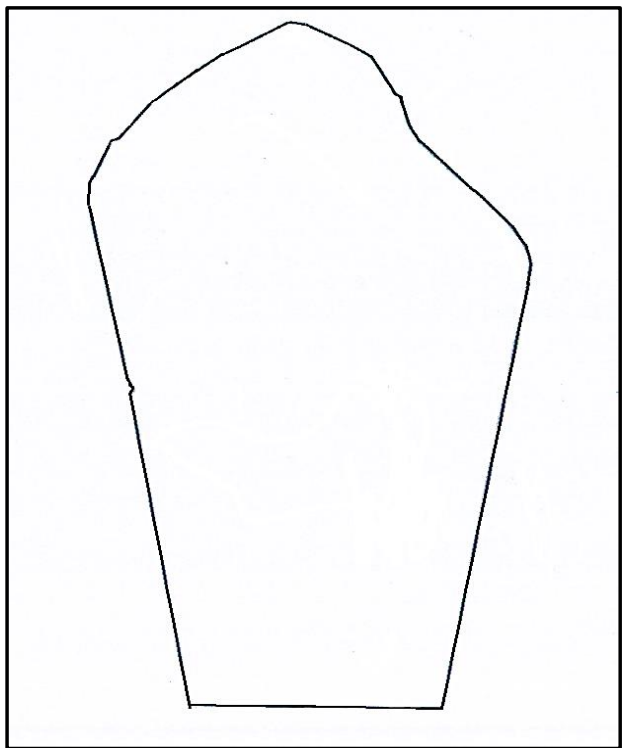

Ayaktaşı Çizim No:2

Cücezâde Es-Seyyid Mehmed Efendi

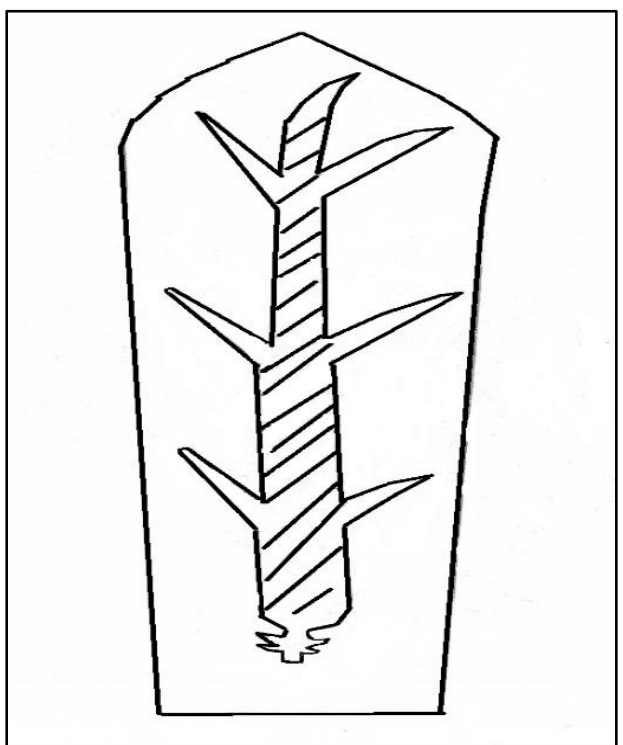


ESOGÜ TARİH DERGISII

Cilt: 4, Sayı:1, 2021, 38 - 74

Başlık Çizim No: 1 /Mehmed Sâlih Efendi

Başlık Ön Yüz

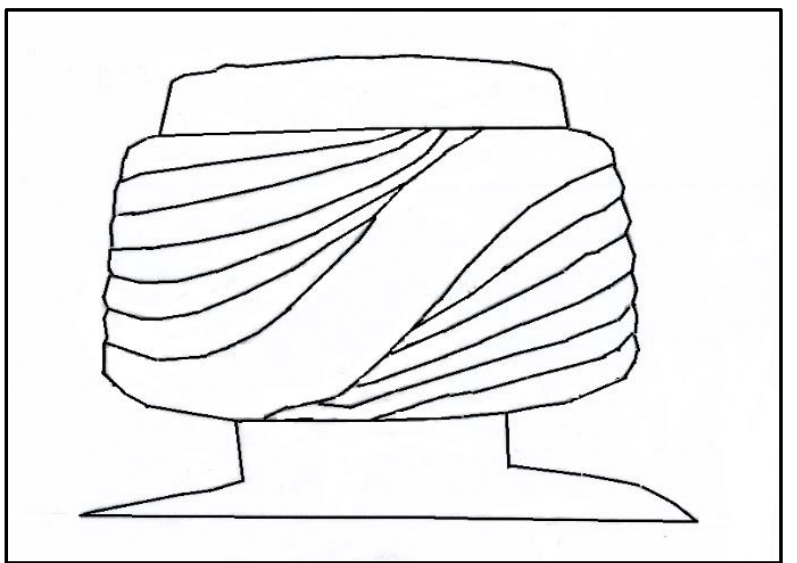

Başlık Çizim No:2/Hâcı Kara Mehmedzâde İbrahim Efendi

Bașlık Ön Yüz

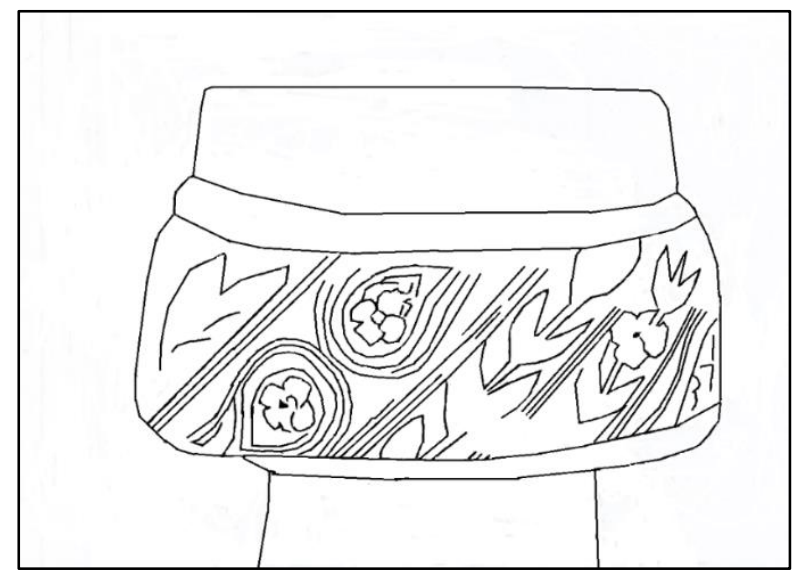


ESOGÜ TARİH DERGISII

Cilt: 4, Sayı:1, 2021, 38 - 74

Başlık Çizim No:3/ Hâcı Kara Mehmedzâde İbrâhim Efendi

Başlık Arka Yüz

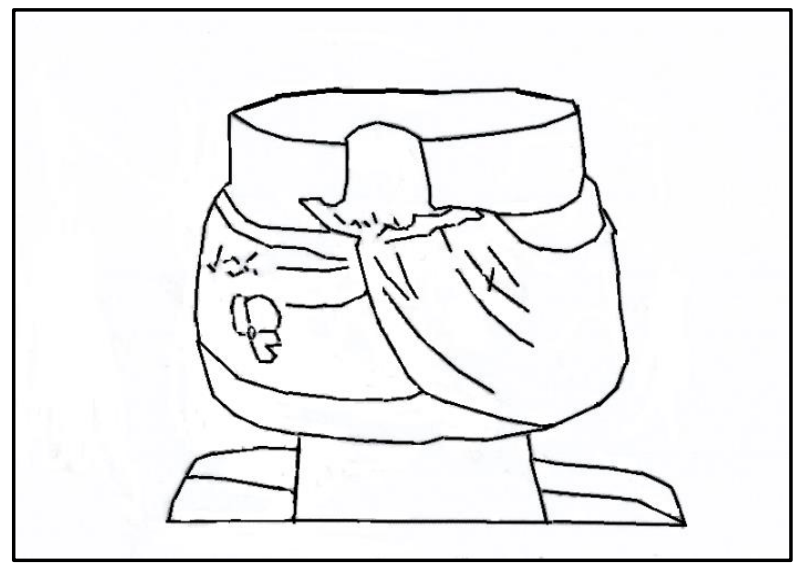


ESOGÜ TARİH DERGİSI

Cilt: 4, Sayı:1, 2021, $38-74$

\section{HARITA VE RESIMLER}

Harita-I/ Aşağı Nazilli Yahya Paşa Cami Yerleşimi

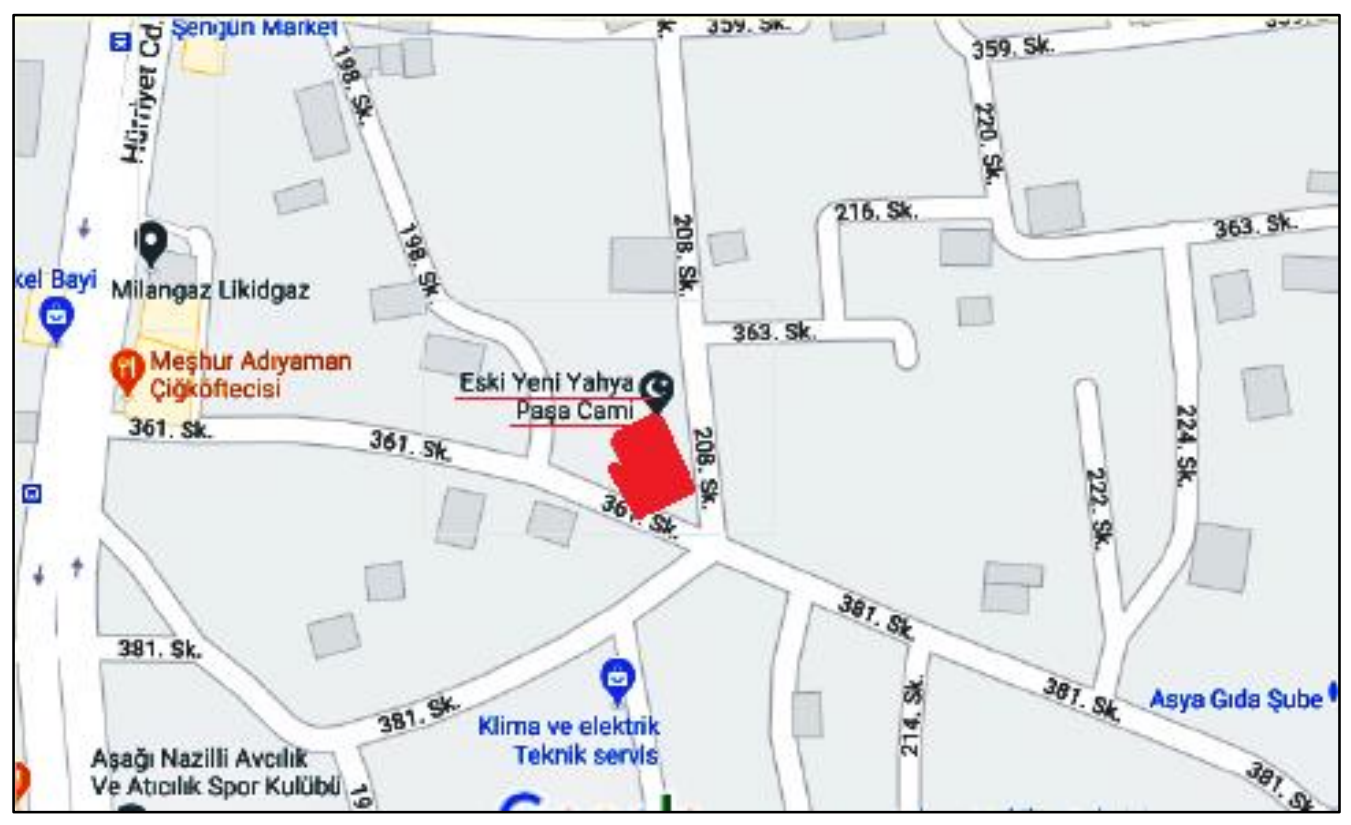

Harita-II/ Yahya Paşa Cami Hazire Yerleşimi

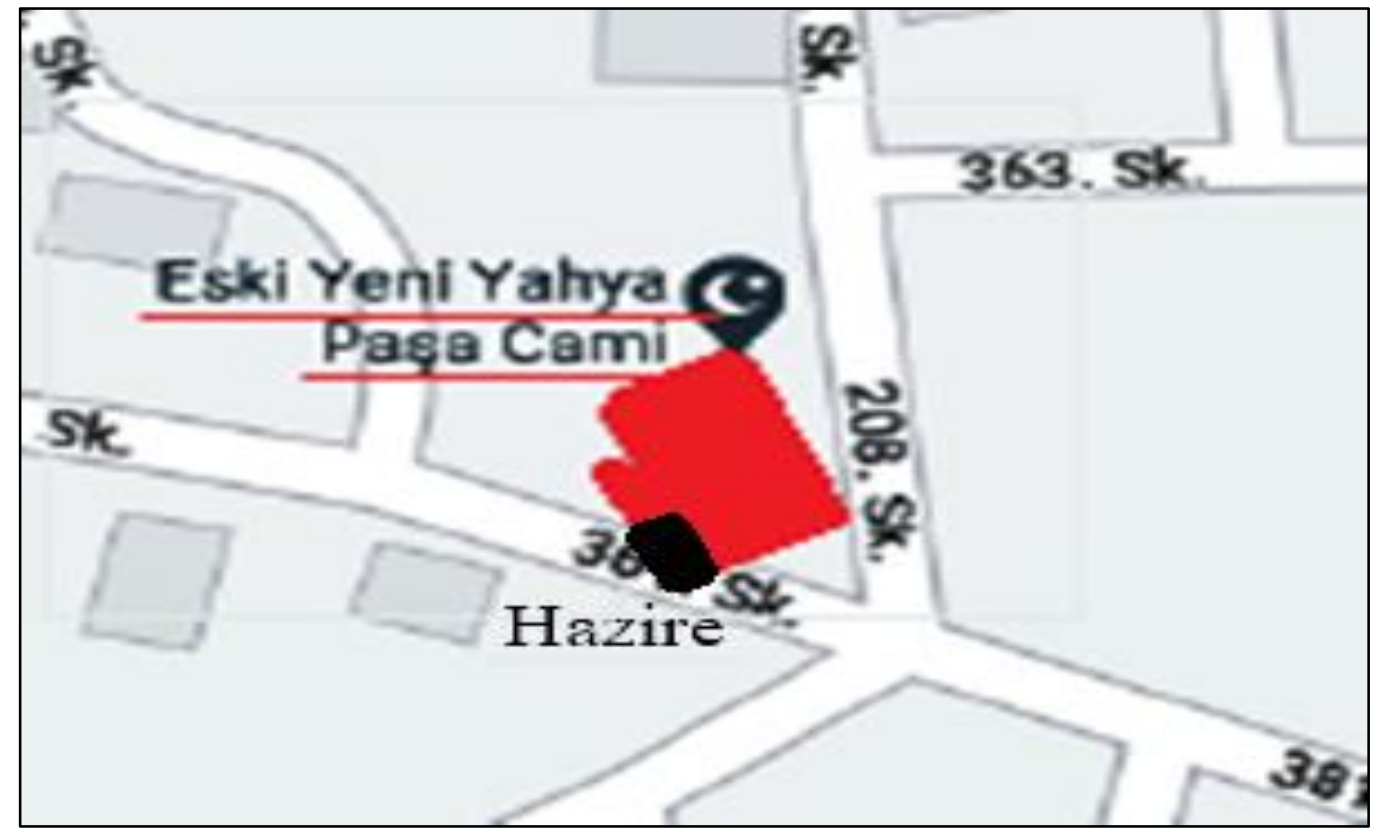


ESOGÜ TARİH DERGISII

Cilt: 4, Sayı:1, 2021, $38-74$

Resim-I /Yahya Paşa Cami Genel Görünüm

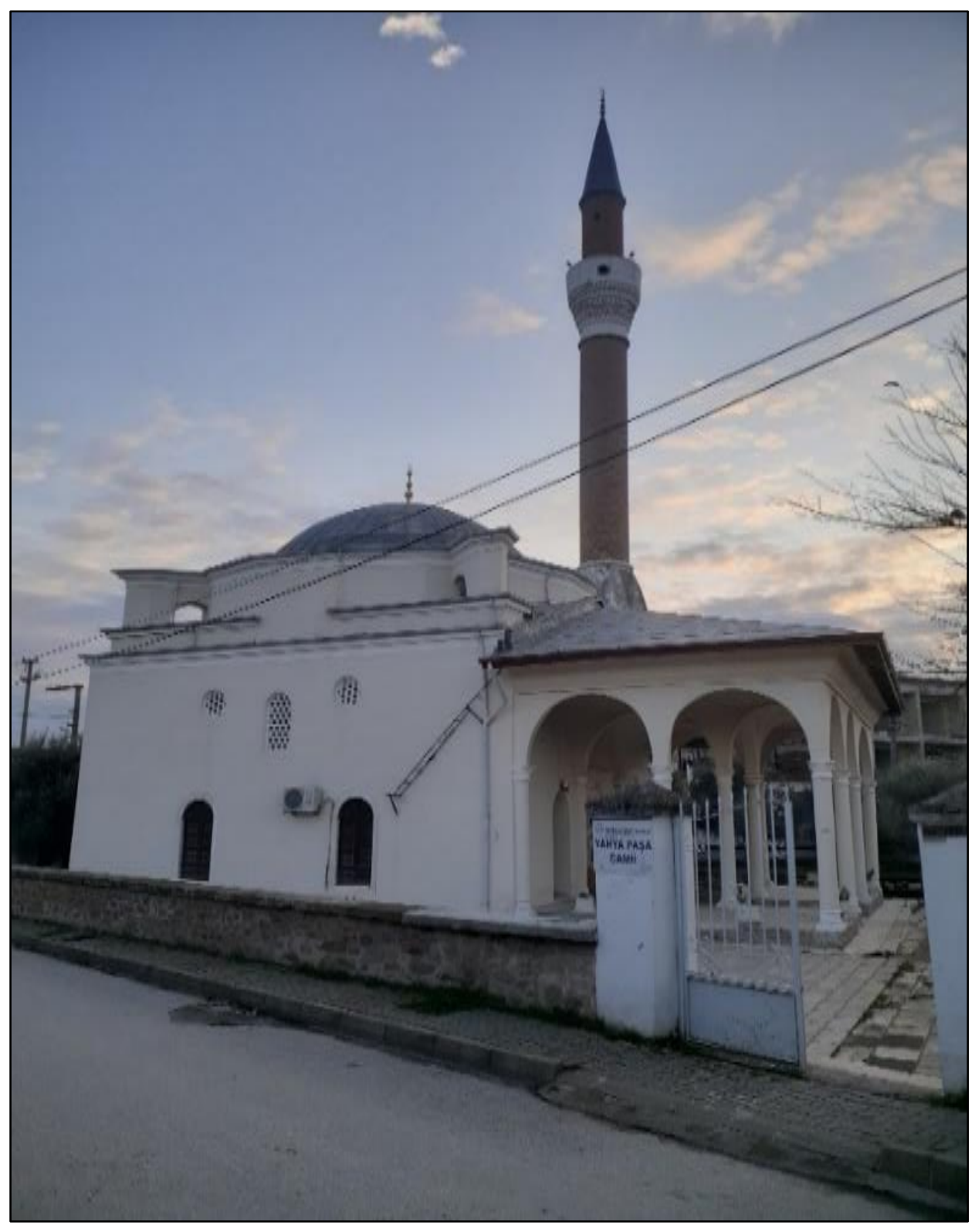


ESOGÜ TARİH DERGİSI

Cilt: 4, Sayı:1, 2021, $38-74$

Resim-II/ Yahya Paşa Cami Son Cemaat Yeri Görünüm

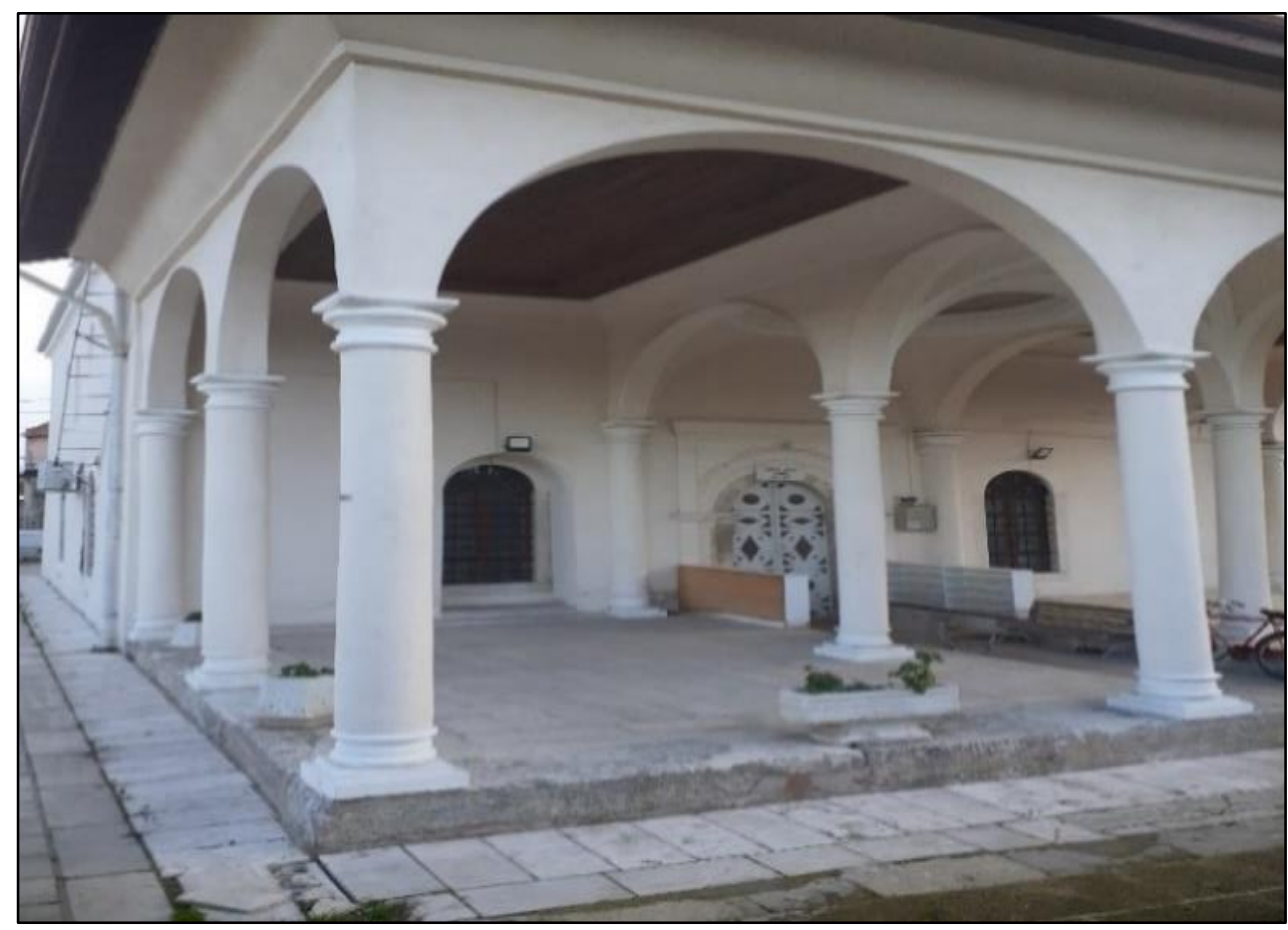

Resim-III/ Yahya Paşa Cami Haziresi Görünüm

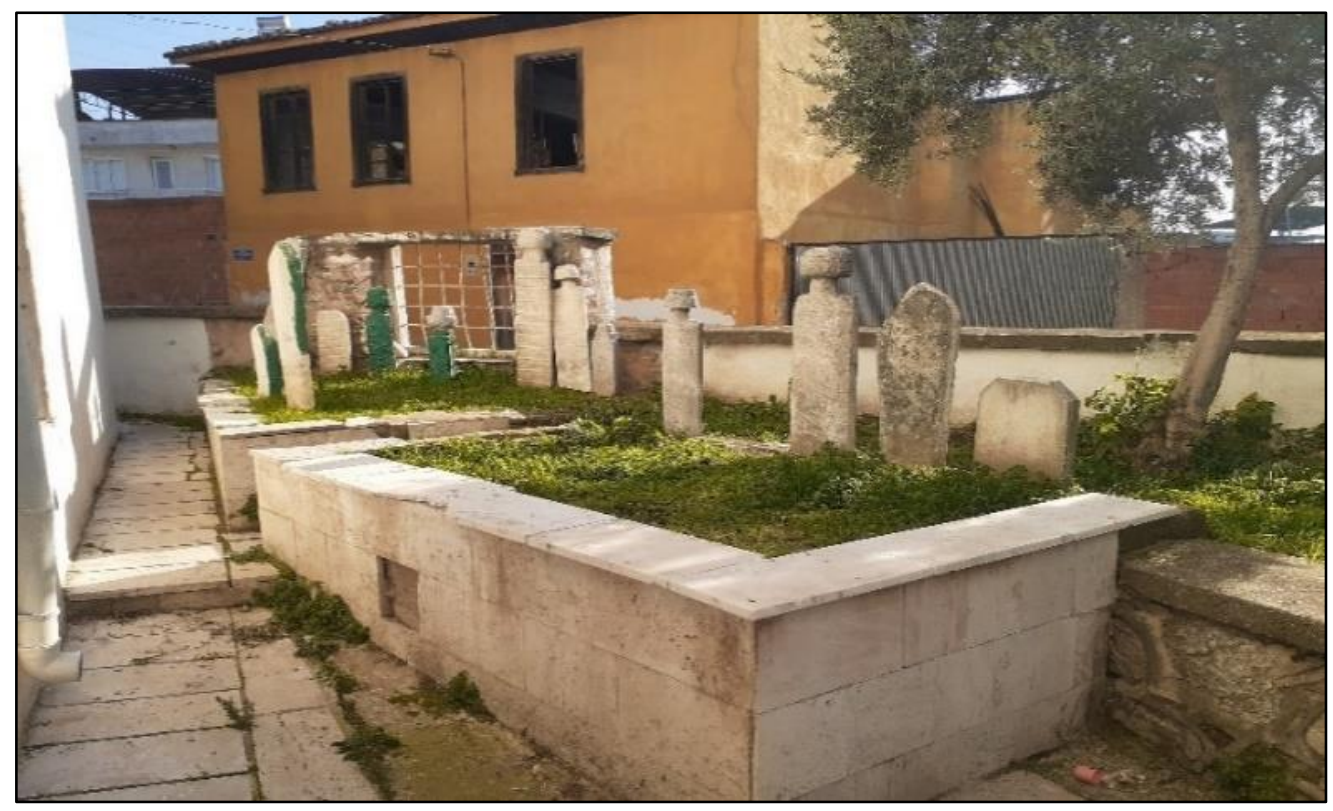


ESOGÜ TARİH DERGİSI

Cilt: 4, Sayı:1, 2021, $38-74$

Resim-IV/Yahya Paşa Haziresi Dış Duvar Yatay Pencere Sövesi

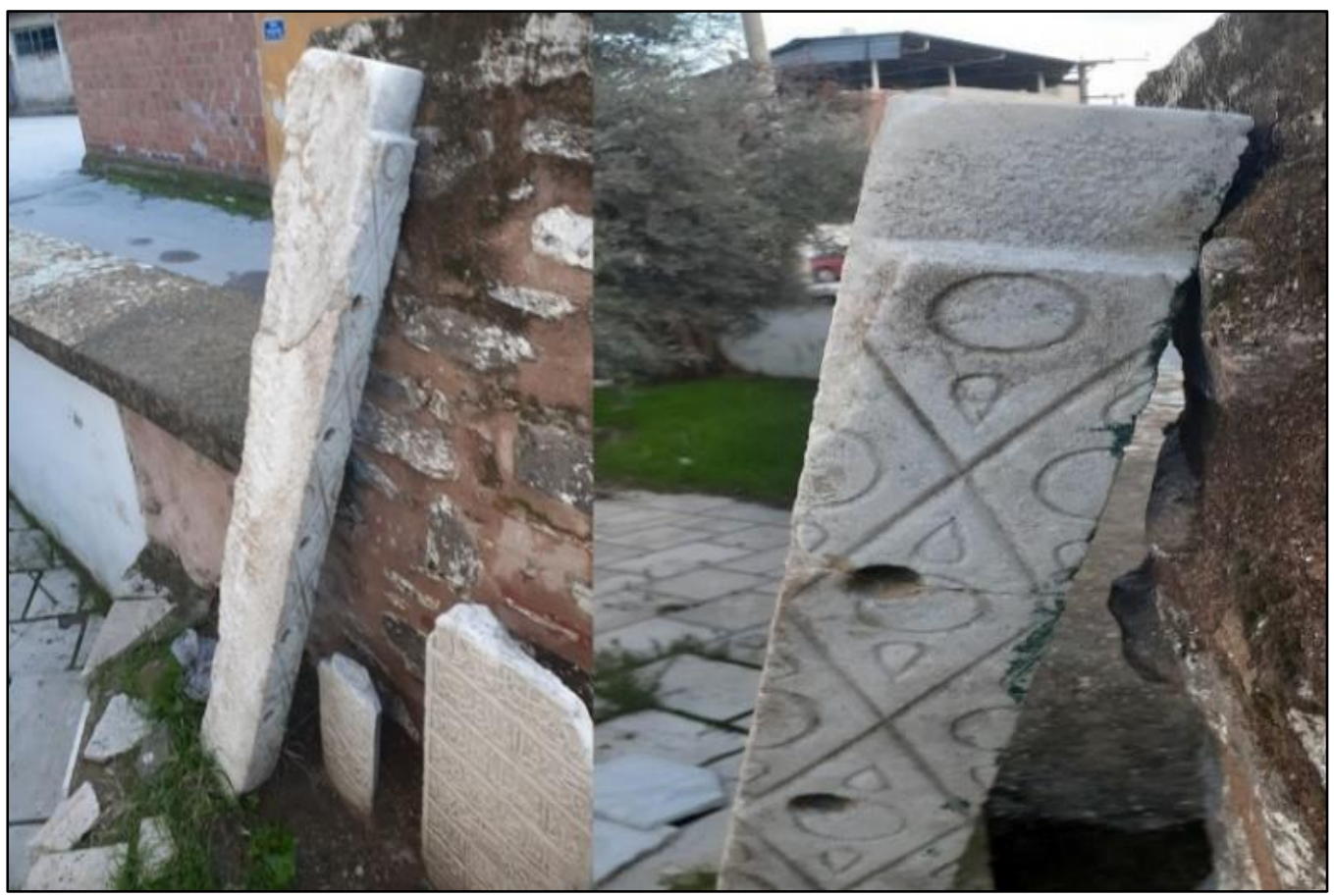

Resim-V/Yahya Paşa Cami Hazire Şebekesi

D1ş Duvar Pencere Söveleri

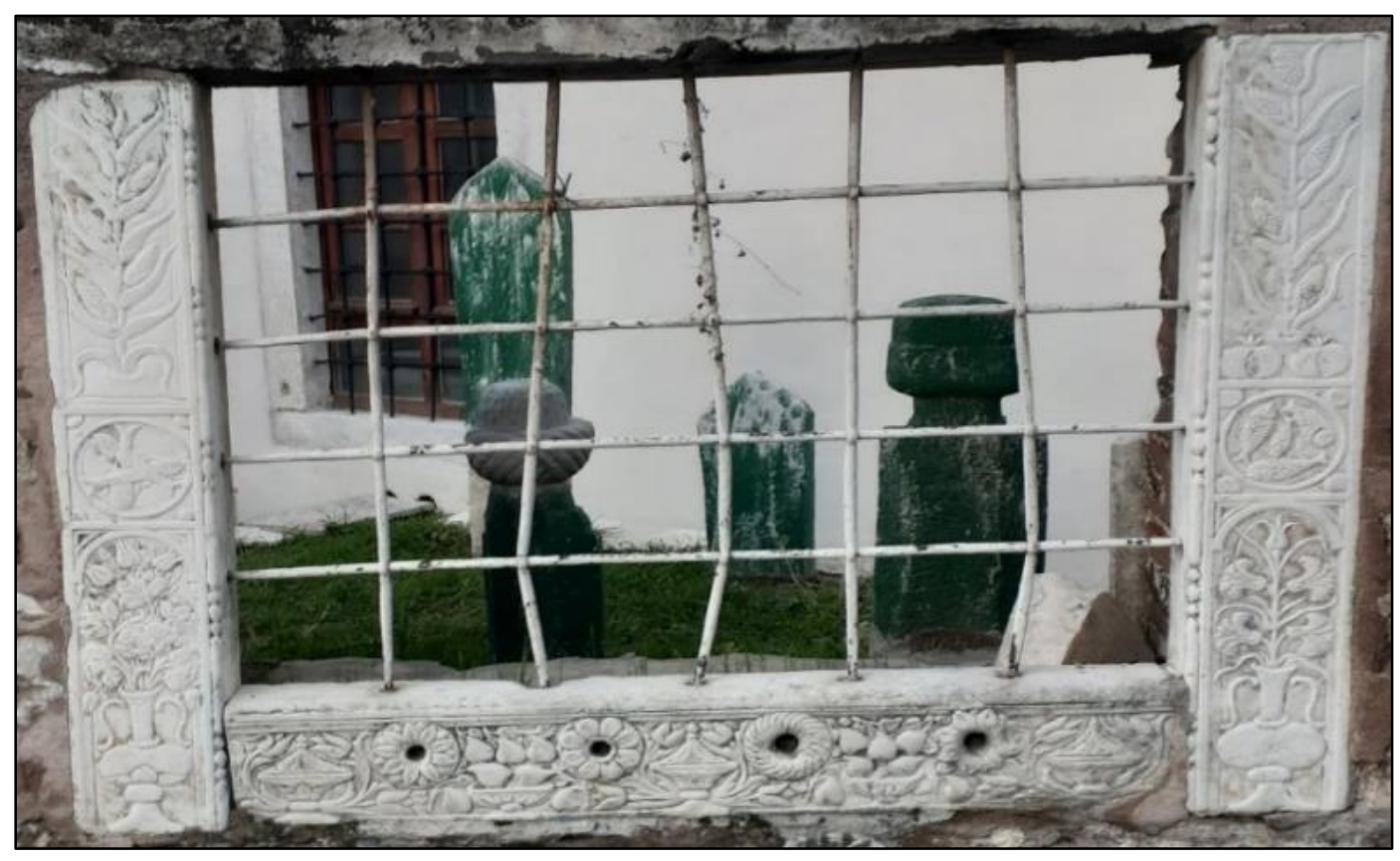


ESOGÜ TARİH DERGISII

Cilt: 4, Sayı:1, 2021, 38 - 74

Resim VI- Müftizâde Ailesinden Hâcı Nûrî Efendizâde

Mustafâ Efendi Mezar Taşı

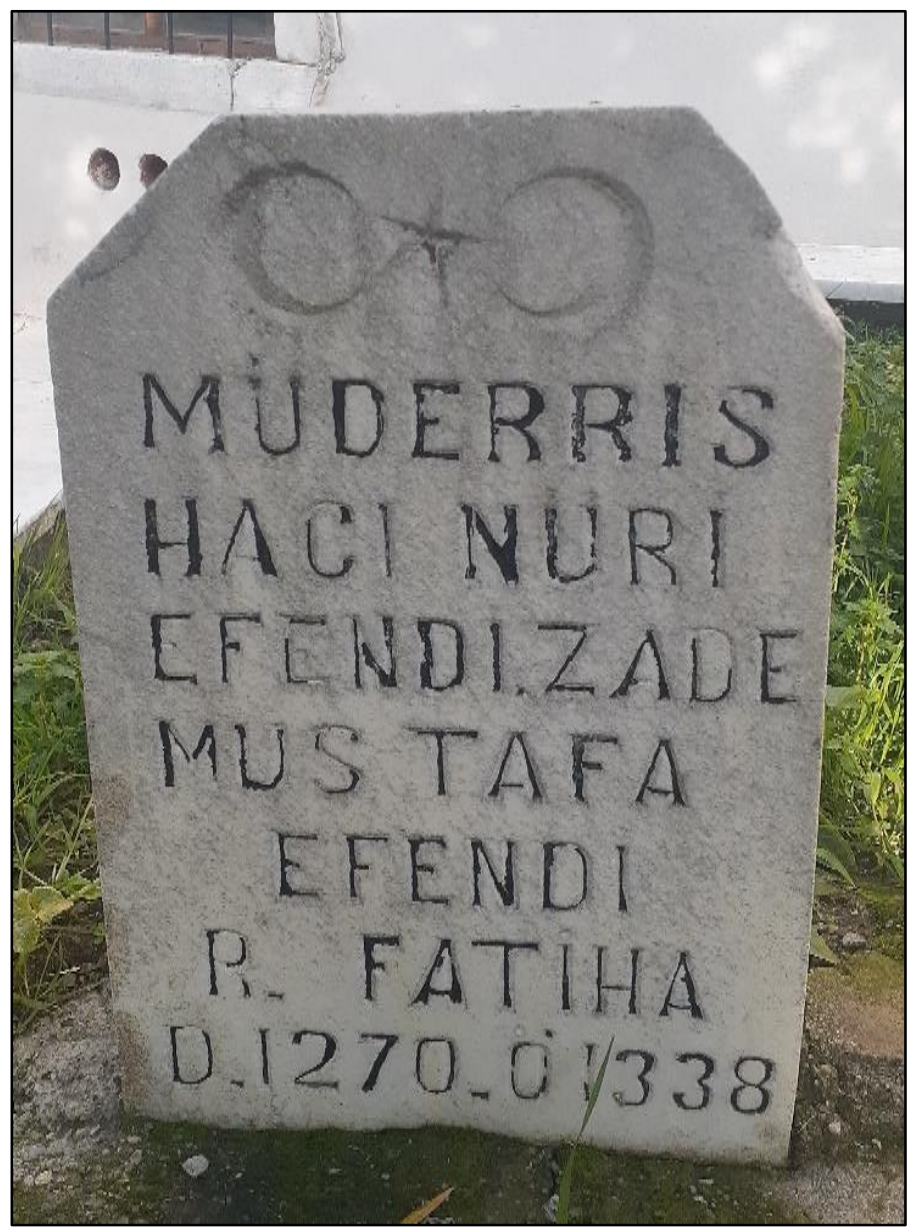

